\title{
The Relationship between Inequality and Growth: Evidence from New Data
}

\author{
Costanza Naguib ${ }^{a}$
}

JEL-Classification: D30, O40

Keywords: income inequality, wealth inequality, Gini coefficient, economic growth, dynamic panel data, GMM estimation

\section{SUMMARY}

The relationship between inequality and growth has attracted a lot of attention in the previous literature. Estimation of this relationship may be biased by simultaneity, omitted variables and measurement error. The present paper contributes to the existing work by introducing the wealth Gini coefficient as a new inequality measure. The most reliable and recent data on income inequality are used for estimation. We employ the Arellano-Bond GMM estimation technique and we find that there seems to be a positive relationship between wealth inequality and real per capita GDP growth, but this relationship is not robust to different model specifications.

a Institute for Economic Research, Università della Svizzera italiana, 6900 Lugano, Switzerland. Tel.: +41 58666 4169. E-mail: costanza.naguib@usi.ch. I would like to thank the Editor Volker Grossmann and two anonymous referees for their insightful suggestions. 


\section{Introduction}

The aim of this paper is to analyze the relationship between inequality and economic growth. To this objective, we compare the impact of income inequality and wealth inequality on real per capita GDP growth. Our main contribution is the use of the wealth Gini coefficient as a measure of inequality; in the previous literature, in fact, the relationship between wealth inequality and GDP growth has rarely been studied.

In recent decades, indeed, considerable efforts have been devoted to assessing the impact of inequality on economic growth. However, most of the previous research focused on income inequality rather than on wealth inequality, due to data scarcity on the latter. The impact of wealth inequality on economic growth has rarely been analyzed in the literature. Moreover, in the few studies that have tackled this issue, wealth concentration has been studied by means of proxies, e.g. the number of billionaires present in the countries, due to the impossibility of constructing a proper wealth Gini coefficient.

To the best of our knowledge, only a few papers have tried to include wealth inequality proxies in the growth regression. DeININGer and SQUiRe (1998) and Balisacan and Fuwa (2003), for example, introduce the Gini coefficient computed for land ownership. However, this variable is likely to be relevant only for those countries in which the primary sector accounts for a fundamental share of GDP. On the contrary, land ownership concentration probably has a smaller influence on economic growth within industrialized economies.

Bagchi and Svejnar (2015) construct an index of wealth inequality based on the lists of billionaires published by Forbes magazine. However, with their approach only the top of the wealth distribution is considered. It is reasonable to suppose, instead, that the entire profile of the wealth distribution has an influence on economic growth.

In this paper, we aim at shedding new light on this relatively new topic by making use of recent estimates of the wealth Gini coefficient in a large sample of countries. We argue that point-in-time income inequality measures, such as the income Gini coefficient, are unsatisfactory measures of lifetime income inequality. From this viewpoint, indeed, wealth inequality is likely to provide a more precise picture of the degree of inequality in the distribution of resources over the entire individual life-cycle (Corneo et al., 2015).

Indeed, as Corneo et al. (2015) point out, income inequality measured in a single year is higher than life-time income inequality; therefore, taking the former as a reference would lead to an over-estimation of the degree of inequality within an economy. In addition, wealth inequality is likely to be more persistent over 
time than income inequality, since a large share of wealth is inherited. Therefore, income inequality and wealth inequality constitute different issues, to be tackled with different policy instruments.

The study of the impact of wealth inequality on real per capita GDP growth is highly relevant today. As shown by Piketry (2014) and by Piketty and Zucman (2015), indeed, in the late $20^{\text {th }}$ and at the beginning of the $21^{\text {st }}$ centuries, both the wealth-income ratio and wealth inequality have been steadily increasing. PIKeTty and ZuCMAN (2015) suggest that, due to low population growth and low productivity growth, this upward trend will continue in the next decades.

Therefore, in such an environment characterized by increasing concentration of resources, it becomes of fundamental importance to understand whether a high level of wealth inequality may hinder economic growth. Such a finding, indeed, would imply that redistributive policies aimed at reducing wealth inequality, and not only income inequality (e.g. capital taxes or inheritance taxes), are necessary in order to enhance real per capita GDP growth.

However, our estimation results show that, when the estimated coefficient attached to wealth Gini is statistically significant, it is always positive. This means that, if there is an impact of wealth inequality on economic growth, this effect is positive, i.e. more wealth inequality is associated with faster economic growth. However, the size of this estimated coefficient is not stable across alternative model specifications.

Moreover, the statistical significance of the estimated coefficient of the wealth Gini seems to depend heavily on the model specification chosen. We conclude that the relationship between the wealth Gini coefficient and real GDP per capita growth is not robust to alternative model specifications. Therefore, no conclusive evidence is found in favor of a clear and stable relationship between the two variables of interest. The same holds for the relationship between income Gini and real GDP per capita growth, i.e. we find no robust relationship between these two variables.

The remainder of the present paper is organized as follows; section 2 will present an overview of the previous literature. Section 3 will explore the data and explain the estimation strategy employed, whereas section 4 will be focused on the comment of the estimation results. Section 5 will conclude. 


\section{Literature Review}

The number of contributions devoted to the analysis of the relationship between inequality and GDP growth in the previous literature is enormous and a comprehensive review of all of them lies beyond the scope of the present paper. This section is structured as follows: first, an overview of the existing theoretical work on the relationship between inequality and growth will be presented. Second, some more specific issues will be analyzed with reference to past literature: the choice of the data, the model formulation and the estimation method.

Table 1 at the end of the present section summarizes the main features of the most relevant and recent empirical studies on this theme.

\subsection{Overview of the Literature}

From a theoretical viewpoint, several transmission channels have been identified, in order to explain how inequality may affect growth. An unequal resource distribution may stimulate investments, innovation and individual effort, therefore enhancing economic growth. On the other hand, it is possible to argue that inequality, in combination with credit market constraints, reduces the number of entrepreneurial projects that can be realized. In addition, if the resource distribution is widely perceived as unfair, social and political unrest may break out. A similar situation would bring about a greater degree of macroeconomic volatility, which, in turn, is associated with lower GDP growth rates.

A relevant concern in previous studies is that of endogeneity of the inequality variable: it is plausible, indeed, that the level of development reached by a country has an influence, in turn, on the domestic inequality level. This direction of research has been explored by several studies following KuZNETs' (1955) hypothesis. KuzneTs (1955) claims that, at the first stages of development, a high degree of inequality in the distribution of resources is necessary, in order to allow the realization of large investments, which in turn will make factor productivity rise. In addition, high wage inequality stimulates workers to seek employment in innovative sectors, which are characterized by higher labor productivity and therefore higher wages. This is another factor which enhances GDP growth. However, after a certain level of economic development has been achieved, demand of the civil society for a more egalitarian resource distribution prompts the government to introduce a welfare system, in order to smooth inequalities.

Therefore, Kuznets suggests that inequality is the dependent variable and economic growth the dependent one. The author further claims that the relationship between the two variables takes the form of an inverted U. It is possible, indeed, 
that only countries that have reached a certain degree of development can afford a redistributive system, which is able to reduce inequality (EASTERLY, 2007).

Kuznets' hypothesis has been challenged by several empirical studies. RavALLION (1995), for example, suggests that there is an absence of a systematic impact of growth on inequality. ADAms (2004), too, finds evidence that there is no statistically significant relationship between inequality and economic growth. He further challenges the widespread belief that growth leads to an increase in inequality in developing economies.

PiketTy (2007 and 2010), too, puts into question Kuznets' hypothesis. Piketty claims that, between the end of the $19^{\text {th }}$ and the beginning of the $20^{\text {th }}$ centuries, France, the UK and the US witnessed an unambiguous upward trend in wealth concentration. This evolution is in striking contrast to Kuznets' prediction of declining inequality after the initial stages of industrialization. In general, Piketty finds no evidence of a systematic downward trend of inequality in Western economies during the $20^{\text {th }}$ century. The above-presented results seem to suggest that the problem of endogeneity of the Gini coefficient in the growth regression may be less serious than was previously thought; however, this issue cannot be neglected and will be further analyzed in the next section.

It is worth noting that empirical results on the theme of the relationship between inequality and economic growth are mixed; for example, Persson and Tabellini (1994), Alesina and Rodrik (1994) and Castelló-Climent (2010) find evidence of a negative relationship between the two variables of interest. They conclude that inequality hinders growth. On the contrary, Li and Zou (1998), Forbes (2000) and Balisacan and Fuwa (2003) claim that the relationship between inequality and growth is positive. It has been argued that the large difference in the results obtained depends on differences in data quality, in the estimation method or in the time horizon considered (KNOwLES, 2001; VoITCHOvsкy, 2005). It is also possible that these differences arise due to the lack of robustness of the relationship considered.

\subsection{The Data Issue}

Most of the previous studies on this theme largely differ in the data, the model formulation or the estimation method used. In the present paper, the more recent and accurate available dataset on income inequality will be used, i.e. the latest release of the SWIID (SolT, 2014). Yearly data will be used for estimation. On this theme, Pagano (2004), Wan, Lu and Chen (2006) and Herzer and Vollmer (2012) claim that the common practice of averaging data should be dismissed, since the length of the interval is essentially arbitrary. In principle, 
averaging should eliminate short-term business cycle fluctuation, but there is no guarantee that such cycles are correctly "cut", given that their length may vary across time and countries. In addition, a considerable amount of information provided by annual data is lost.

As for the inequality variable, the Gini coefficient is the most widely used measure of inequality. Different data sources can be used in order to calculate this. In some cases, the individual is considered as a reference unit, whereas in other cases the same role is attributed to the household. Furthermore, data can be recorded on the basis of different income definitions (gross or net) or even on the basis of expenditure. As explained above, the present work benefits from the use of the SWIID, which minimizes such comparability problems.

\subsection{The Model Formulation Issue}

With reference to the formulation of the growth equation, there is currently no agreement on the adequacy of a linear model. BARRO (2000), for example, warns against the presence of non-linearities in the analysis of the relationship between inequality and growth. BAnerJeE and Duflo (2003) find evidence that both increases and decreases in inequality cause a reduction in the growth rate of an economy, i.e. the relationship between the two variables takes the form of an inverted "U". Chen (2003) puts forward a similar claim. The author suggests that, at low levels of inequality, further redistributive policies may hurt growth. On the contrary, when the inequality level is high, a redistribution of resources in the sense of greater equality may be beneficial for GDP growth.

A common strategy for tackling the issue of nonlinearity consists of including squared terms as well as interaction terms in the estimating equation. Interaction terms between inequality and the other explanatory variables are particularly relevant, since they allow assessment of whether the impact of inequality on economic growth is moderated or magnified by some other factor (NoH and Yoo, 2008). De la Croix and Doepke (2003) report that most of the interaction terms are never statistically significant. With reference to transition economies, SUKIasSYaN (2007) finds evidence that the estimated coefficients of the squared Gini terms are not statistically significant in all model specifications; therefore, the impact of nonlinearities on the estimation result may not be as dramatic as thought. However, in this work both squared Gini terms and interaction terms between the Gini and the controls will be introduced, in order to check the robustness of the results.

Moreover, there is currently no agreement in the literature on whether the relationship between the two variables of interest changes or not depending on the initial level of per capita income. Barro (2000 and 2008) and Grijalva (2011) 
claim that inequality is bad for growth in poor countries, whereas it constitutes a stimulus for growth in rich ones. On the contrary, Bleaney and Nishiyama (2004) find no evidence of a significant difference in the estimated coefficients for the Gini between rich and poor countries. To provide further evidence on that point, an interaction term between inequality and initial GDP per capita will be introduced in our model.

\subsection{The Estimation Method Issue}

As far as the estimation method is concerned, cross-section results probably suffer from omitted variable bias, since different countries are likely to be heterogeneous. In order to minimize distortions due to omitted variables, a Fixed Effects estimate should be preferred. This method, in fact, eliminates unobserved timeinvariant country-specific effects that may be correlated with the explanatory variables (NoH and Yoo, 2008; Forbes, 2000).

In the previous literature, lagged values of per capita GDP have been widely included among the explanatory variables, in order to take into account the effect of the so-called "knowledge gap" between countries. According to economic theory, the larger the "knowledge gap", the easier it is for a country to raise its domestic productivity by learning, imitating and modifying technology already introduced by the leading economies (Mo, 2000; Kostov and Le Gallo, 2015). Therefore, the expected sign of the estimated coefficient is negative. FALLAH and Partridge (2007), too, suggest that the inclusion of the logarithm of the initial per capita income may allow us to capture conditional convergence. BASU and GuARIGLIA (2007) introduce the five-year lag of the logarithm of real GDP per capita in the growth equation, in order to take into account conditional convergence. Chambers and Krause (2010), too, include five-year lags of income per capita among the explanatory variables. Due to the introduction of the initial income term, the model becomes dynamic; therefore, both Random Effects and Fixed Effects estimates are biased and inconsistent.

In order to tackle the problem of endogeneity of the inequality variable, as well as of the other covariates, instrumental variables (IV) have been widely used in the previous literature. However, finding valid instruments is not straightforward. De la Croix and Doepke (2003) for example, employ fertility rate and life expectancy, measured at the beginning of the reference period, as instruments for the Gini coefficient. However, both life expectancy and fertility are likely to be heavily influenced by economic growth and therefore to be endogenous as well. The mere fact of considering initial or lagged values of these variables does not provide a guarantee of their exogeneity. 
Bagchi and Svejnar (2015) employ the exchange rate as IV; however, fluctuations of the exchange rate are widely believed to be linked to the monetary policy adopted within a country, which in turn usually depends on the general performance of the economy. It follows that the rate of exchange is likely to depend on the rate of GDP growth, i.e. to be endogenous. EAsterly (2007) proposes an innovative instrument, which is defined by the ratio between the extent of land suitable for wheat and that available for sugarcane cultivation. However, this variable probably has a significant impact within developing economies, but is less relevant in industrialized countries. Given the difficulty of finding valid instrumental variables in a cross-country context, the Generalized Method of Moments has been preferred to the IV estimation technique in the present paper.

Table 1: An Overview of the Existing Literature on the Relationship between Inequality and Growth

\begin{tabular}{|c|c|c|c|c|}
\hline Author & Sample & Inequality measure & $\begin{array}{l}\text { Estimation } \\
\text { method }\end{array}$ & Results \\
\hline $\begin{array}{l}\text { PERSSON and } \\
\text { TABELLINI, } \\
1994\end{array}$ & $\begin{array}{l}67 \text { countries, } \\
1960-85 .\end{array}$ & $\begin{array}{l}\text { Ratio between the } \\
\text { income share of } \\
\text { the bottom } 40 \% \\
\text { and that of the top } \\
20 \% \text {. }\end{array}$ & OLS, 2SLS & Negative relationship \\
\hline $\begin{array}{l}\text { Alesina and } \\
\text { RoDrik, } 1994\end{array}$ & $\begin{array}{l}70 \text { countries, } \\
1960-85 .\end{array}$ & $\begin{array}{l}\text { Income and land } \\
\text { Gini coefficient }\end{array}$ & & Negative relationship \\
\hline Clarke, 1995 & $\begin{array}{l}70 \text { countries, } \\
1970-88 .\end{array}$ & $\begin{array}{l}\text { Gini coefficient, } \\
\text { Theil index, } \\
\text { ratio between the } \\
\text { income share of } \\
\text { the bottom } 40 \% \\
\text { and that of the top } \\
20 \% \text {. }\end{array}$ & OLS, 2SLS & Negative relationship \\
\hline Perotti, 1996 & 67 countries, & $\begin{array}{l}\text { Income share of } \\
\text { the third and of the } \\
\text { fourth quintile. }\end{array}$ & OLS, IV & Negative relationship \\
\hline $\begin{array}{l}\text { DeININGER } \\
\text { and SQuire, } \\
1998\end{array}$ & $\begin{array}{l}87 \text { countries, } \\
1960-92 .\end{array}$ & $\begin{array}{l}\text { Income and land } \\
\text { Gini coefficient }\end{array}$ & OLS & $\begin{array}{l}\text { Negative relationship, } \\
\text { which becomes statistically } \\
\text { insignificant with the } \\
\text { inclusion of continent } \\
\text { dummies. }\end{array}$ \\
\hline
\end{tabular}




\begin{tabular}{|c|c|c|c|c|}
\hline Author & Sample & Inequality measure & $\begin{array}{l}\text { Estimation } \\
\text { method }\end{array}$ & Results \\
\hline $\begin{array}{l}\text { DeININGER } \\
\text { and Olinto, } \\
1999\end{array}$ & $\begin{array}{l}60 \text { countries, } \\
1966-1990\end{array}$ & $\begin{array}{l}\text { Income and land } \\
\text { Gini coefficient }\end{array}$ & $\begin{array}{l}\text { System } \\
\text { GMM }\end{array}$ & $\begin{array}{l}\text { Negative impact of land } \\
\text { inequality and positive } \\
\text { impact of income } \\
\text { inequality on economic } \\
\text { growth. }\end{array}$ \\
\hline $\begin{array}{l}\text { Li and Zou, } \\
1998\end{array}$ & $\begin{array}{l}46 \text { countries, } \\
1960-90 .\end{array}$ & $\begin{array}{l}\text { Income Gini } \\
\text { coefficient }\end{array}$ & FE, RE & Positive relationship \\
\hline Forbes, 2000 & $\begin{array}{l}45-67 \\
\text { countries, } \\
1970-95 .\end{array}$ & $\begin{array}{l}\text { Income Gini } \\
\text { coefficient }\end{array}$ & $\begin{array}{l}\text { FE, RE, } \\
\text { difference } \\
\text { GMM }\end{array}$ & Positive relationship \\
\hline Mo, 2000 & $\begin{array}{l}20 \text { countries, } \\
1970-85\end{array}$ & $\begin{array}{l}\text { Income Gini } \\
\text { coefficient }\end{array}$ & 2SLS & Negative relationship \\
\hline $\begin{array}{l}\text { BANERJEe and } \\
\text { Duflo, } 2003\end{array}$ & $\begin{array}{l}45 \text { countries, } \\
1965-90 .\end{array}$ & $\begin{array}{l}\text { Income Gini } \\
\text { coefficient }\end{array}$ & $\begin{array}{l}\text { FE, RE, } \\
\text { difference } \\
\text { GMM }\end{array}$ & $\begin{array}{l}\text { Changes in inequality in } \\
\text { whatever direction are } \\
\text { associated to negative } \\
\text { changes in the growth } \\
\text { rate. }\end{array}$ \\
\hline $\begin{array}{l}\text { BALISACAN and } \\
\text { FuWA, } 2003\end{array}$ & $\begin{array}{l}\text { Philippines, } \\
\text { provincial } \\
\text { data, 1988-97 }\end{array}$ & $\begin{array}{l}\text { Land Gini } \\
\text { coefficient }\end{array}$ & OLS, IV & Positive relationship \\
\hline Chen, 2003 & $\begin{array}{l}54 \text { countries, } \\
1970-1992\end{array}$ & $\begin{array}{l}\text { Income Gini } \\
\text { coefficient }\end{array}$ & $\begin{array}{l}\text { OLS with } \\
\text { Gini squared } \\
\text { among the } \\
\text { covariates }\end{array}$ & $\begin{array}{l}\text { Inverted-U relationship } \\
\text { between income inequality } \\
\text { and growth. }\end{array}$ \\
\hline $\begin{array}{l}\text { De La Croix } \\
\text { and Doepke, } \\
2003\end{array}$ & $\begin{array}{l}68 \text { countries, } \\
1960-1992\end{array}$ & $\begin{array}{l}\text { Income Gini } \\
\text { coefficient }\end{array}$ & $\begin{array}{l}\text { Difference } \\
\text { GMM }\end{array}$ & $\begin{array}{l}\text { Negative relationship, } \\
\text { which becomes non- } \\
\text { significant if fertility rate } \\
\text { is taken into account. }\end{array}$ \\
\hline $\begin{array}{l}\text { Gylfason and } \\
\text { Zoega, } 2003\end{array}$ & $\begin{array}{l}87 \text { countries, } \\
1965-98\end{array}$ & $\begin{array}{l}\text { Income Gini } \\
\text { coefficient }\end{array}$ & SUR & Negative relationship \\
\hline Pagano, 2004 & $\begin{array}{l}40 \text { countries, } \\
1950-1990\end{array}$ & $\begin{array}{l}\text { Income Gini } \\
\text { coefficient }\end{array}$ & $\begin{array}{l}\text { Difference } \\
\text { and system } \\
\text { GMM }\end{array}$ & $\begin{array}{l}\text { Positive relationship in } \\
\text { rich countries, negative } \\
\text { relationship in poor ones. }\end{array}$ \\
\hline IRADIAN, 2005 & $\begin{array}{l}82 \text { countries, } \\
1965-2003\end{array}$ & $\begin{array}{l}\text { Income Gini } \\
\text { coefficient }\end{array}$ & $\begin{array}{l}\text { FE and } \\
\text { difference } \\
\text { GMM }\end{array}$ & $\begin{array}{l}\text { Positive relationship in } \\
\text { the short-medium term, } \\
\text { which becomes negative in } \\
\text { the long term. }\end{array}$ \\
\hline $\begin{array}{l}\text { KNOWLES, } \\
2005\end{array}$ & $\begin{array}{l}40 \text { countries, } \\
1960-90 .\end{array}$ & $\begin{array}{l}\text { Income Gini } \\
\text { coefficient }\end{array}$ & OLS & Negative relationship \\
\hline
\end{tabular}




\begin{tabular}{|c|c|c|c|c|}
\hline Author & Sample & Inequality measure & $\begin{array}{l}\text { Estimation } \\
\text { method }\end{array}$ & Results \\
\hline $\begin{array}{l}\text { Wan, Lu, and } \\
\text { Chen, } 2006\end{array}$ & $\begin{array}{l}\text { China, } 29 \\
\text { regions, } \\
1987-98\end{array}$ & $\begin{array}{l}\text { Urban-rural per } \\
\text { capita income ratio }\end{array}$ & $\begin{array}{l}\text { Polynomial } \\
\text { inverse lag } \\
\text { model, 3SLS }\end{array}$ & $\begin{array}{l}\text { Negative nonlinear } \\
\text { relationship }\end{array}$ \\
\hline $\begin{array}{l}\text { EASTERLY, } \\
2007\end{array}$ & $\begin{array}{l}100 \text { countries, } \\
1960-98 .\end{array}$ & $\begin{array}{l}\text { Income Gini } \\
\text { coefficient, share of } \\
\text { top income quintile }\end{array}$ & OLS, IV & Negative relationship \\
\hline $\begin{array}{l}\text { SUKIASSYAN, } \\
2007\end{array}$ & $\begin{array}{l}26 \text { transition } \\
\text { economies, } \\
1988-2002\end{array}$ & $\begin{array}{l}\text { Income Gini } \\
\text { coefficient }\end{array}$ & $\begin{array}{l}\text { OLS and } \\
\text { difference } \\
\text { GMM with } \\
\text { Gini squared } \\
\text { among the } \\
\text { covariates }\end{array}$ & $\begin{array}{l}\text { Negative relationship. The } \\
\text { author finds no empirical } \\
\text { support for nonlinearities. }\end{array}$ \\
\hline
\end{tabular}

\begin{tabular}{|c|c|c|c|c|}
\hline BARRo, 2008 & $\begin{array}{l}47-70 \\
\text { countries, } \\
1965-2003 / 4\end{array}$ & $\begin{array}{l}\text { Income Gini } \\
\text { coefficient }\end{array}$ & OLS & $\begin{array}{l}\text { Positive relationship in } \\
\text { rich countries, negative } \\
\text { relationship in the poor } \\
\text { ones. }\end{array}$ \\
\hline $\begin{array}{l}\text { NoH and Yoo, } \\
2008\end{array}$ & $\begin{array}{l}60 \text { countries, } \\
1995-2002\end{array}$ & $\begin{array}{l}\text { Income Gini } \\
\text { coefficient }\end{array}$ & $\mathrm{FE}$ & Positive relationship \\
\hline $\begin{array}{l}\text { LIN and YEH, } \\
2009\end{array}$ & $\begin{array}{l}83 \text { countries, } \\
1965-2003\end{array}$ & $\begin{array}{l}\text { Income Gini } \\
\text { coefficient }\end{array}$ & $\begin{array}{l}\text { SEM, } \\
\text { difference } \\
\text { GMM }\end{array}$ & Negative relationship \\
\hline $\begin{array}{l}\text { Castelló- } \\
\text { Climent, } \\
2010\end{array}$ & $\begin{array}{l}56 \text { countries, } \\
1965-2000\end{array}$ & $\begin{array}{l}\text { Income and } \\
\text { human capital Gini } \\
\text { coefficient }\end{array}$ & $\begin{array}{l}\text { System } \\
\text { GMM }\end{array}$ & Negative relationship \\
\hline $\begin{array}{l}\text { Chambers and } \\
\text { Krause, } 2010\end{array}$ & $\begin{array}{l}54 \text { countries, } \\
1960-2000\end{array}$ & $\begin{array}{l}\text { Income Gini } \\
\text { coefficient }\end{array}$ & $\begin{array}{l}\text { Local } \\
\text { Linear Least } \\
\text { Squares, } \\
\text { Gaussian } \\
\text { kernel }\end{array}$ & Negative relationship \\
\hline Grijalva, 2011 & $\begin{array}{l}100 \text { countries, } \\
1950-2007\end{array}$ & $\begin{array}{l}\text { Income Gini } \\
\text { coefficient }\end{array}$ & $\begin{array}{l}\text { FE, RE, } \\
\text { difference } \\
\text { and system } \\
\text { GMM }\end{array}$ & $\begin{array}{l}\text { Inverted " } U \text { " relationship } \\
\text { the short and medium } \\
\text { term ( } 5-10 \text { years). In } \\
\text { the long term the results } \\
\text { confirm Barro (2008). }\end{array}$ \\
\hline Assa, 2012 & $\begin{array}{l}141 \text { countries, } \\
1998-2008 .\end{array}$ & $\begin{array}{l}\text { Income Gini } \\
\text { coefficient }\end{array}$ & OLS, 2SLS & $\begin{array}{l}\text { Negative relationship in } \\
\text { the developing countries, } \\
\text { less evident in the } \\
\text { advanced economies. }\end{array}$ \\
\hline $\begin{array}{l}\text { Herzer and } \\
\text { Vollmer, } 2012\end{array}$ & $\begin{array}{l}46 \text { countries, } \\
1970-1995\end{array}$ & $\begin{array}{l}\text { Income Gini } \\
\text { coefficient }\end{array}$ & $\begin{array}{l}\text { Panel } \\
\text { cointegration }\end{array}$ & Negative relationship \\
\hline
\end{tabular}




\begin{tabular}{lllll}
\hline Author & Sample & Inequality measure & $\begin{array}{l}\text { Estimation } \\
\text { method }\end{array}$ & Results \\
\hline $\begin{array}{l}\text { RAVALLION, } \\
2012\end{array}$ & $\begin{array}{l}90 \text { countries, } \\
1980-2005\end{array}$ & $\begin{array}{l}\text { Income Gini } \\
\text { coefficient }\end{array}$ & $\begin{array}{l}\text { Difference } \\
\text { GMM }\end{array}$ & $\begin{array}{l}\text { Inequality does not have } \\
\text { a statistically significant } \\
\text { impact on growth once we } \\
\text { control for initial poverty. }\end{array}$ \\
$\begin{array}{l}\text { BAGCHI and } \\
\text { SvEJNAR, 2015 }\end{array}$ & $\begin{array}{l}41 \text { countries, } \\
1987-2002\end{array}$ & $\begin{array}{l}\text { A wealth inequality } \\
\text { index derived by } \\
\text { Forbes magazine's } \\
\text { list of billionaires. }\end{array}$ & RE, FE, IV & Negative relationship \\
& & & \\
\hline
\end{tabular}

Source: Author's own elaboration.

\section{Data and Estimation Strategy ${ }^{1}$}

\subsection{The Sample}

Our main sample includes 146 countries for the years 2010-2014. ${ }^{2}$ In this sample the inequality variable is the wealth Gini coefficient. Most of the estimates reported in section 4 are based on this sample. If a value of the Gini is missing, it is replaced with the nearest value for the same country in the previous five years, similarly to what was done by For BEs (2000). If no such value is available, then the observation is dropped, following the missing-at-random assumption, so the sample is unbalanced.

In a 2011 paper, Davies et al. tried for the first time to estimate the Gini coefficient for wealth ownership in 25 countries, with reference to the year 2000. On that basis, starting from 2010, DAviEs et al. have proposed estimates of the wealth Gini for an increasing sample of countries. These data have been published on a yearly basis by the Credit Suisse Research Institute. These reports constitute our source for the wealth inequality data.

1 Please note that in this section as well as in section 4, whenever we refer to growth or growth rate, we mean "real GDP per capita annual growth rate".

2 Data on wealth Gini are sometimes available for countries and years for which data on income Gini are not available and vice versa. Therefore, the following countries are only included in the wealth sample (146 countries for the years 2010-2014): Bahrain, Brunei Darussalam, Cote d'Ivoire, Oman, Qatar, Samoa, Saudi Arabia, Solomon Islands, St. Kitts and Nevis, Tonga, Vanuatu, West Bank and Gaza. Analogously, the following countries are only included in the income sample (154 countries for the period 1990-2014): Afghanistan, Albania, Armenia, Bhutan, Botswana, Cambodia, Dominican Republic, Ethiopia, Gabon, Guatemala, GuineaBissau, Honduras, Maldives, Namibia, Puerto Rico, Timor-Leste, Trinidad and Tobago, Uzbekistan, Vietnam, Zambia. 
In order to perform some robustness checks, other samples are also considered. First, an extended (unbalanced) sample, which includes 154 countries for the period 1990-2014, has been constructed. Since data on the wealth Gini coefficient are not available for such a long time span, in this case the inequality variable considered is the income Gini coefficient. Our source for the data on the income Gini coefficient is the latest version (5.0, release October 2014) of the Standardized World Inequality Income Database (SWIID).

Second, we trim our main sample by excluding data on wealth Gini that were reported as of "very poor" or "unknown" quality in the Credit Suisse Reports, thus obtaining a high-quality (though still unbalanced) sample of 114 countries for the period 2010-2014. Third, we divide our main sample into two subsamples, one including rich countries and the other including the poorer ones. The division is performed on the basis of the median initial per capita income of the whole sample. In this way, we obtain two subsamples, each including 73 countries, for the period 2010-2014. In these two samples, again, the inequality variable is the wealth Gini coefficient.

It is worth noting here that there are large variations in the values of the wealth Gini as well as of the income Gini from one year to another within the same country. This is particularly evident for the wealth Gini between 2010 and 2011, for example in the cases of Australia, Chile or the United States. Such large variations are likely to be due to updating in the national data sources used by the authors of the Credit Suisse reports as a basis for the computation of the wealth Gini coefficient. The income Gini coefficient also shows for some countries, such as Bulgaria, large variations from one year to another. Hence, we get an indication that our inequality data may still suffer from measurement error.

In the table below some descriptive statistics on the inequality variables are reported. Data on both income Gini and wealth Gini are available only for a subsample of 116 countries in the period 2010-2014. Both income and wealth inequality data show a certain degree of variability across years (within group variation), which is comparable in size to cross-country (between groups) variation. The choice of averaging data has often been justified in the past literature by the claim of time-invariance of the Gini coefficient. From the summary statistics below, however, we can deduce some empirical support for the use of yearly (i.e. non-averaged) data. As one could reasonably expect (see Table 2 below), the mean income Gini is considerably lower than the mean wealth Gini, i.e. wealth is on average more concentrated than income.

The countries with the maximum level of wealth inequality are Cabo Verde in 2012 (wealth Gini coefficient equal to 100) and St. Kitts and Nevis in 2012, with a wealth Gini coefficient equal to 99.7. On the other hand, the countries 
in which wealth seems to be more equally distributed are the Slovak Republic (wealth Gini equal to 44.7 in 2013) and Slovenia (wealth Gini equal to 53.5 in 2013); this is probably due to the historical background (communism) of these last two countries.

Table 2: Summary Statistics of the Income and the Wealth Gini Coefficients

\begin{tabular}{lcccccc}
\hline Variable & Mean & Min & Max & $\begin{array}{c}\text { Overall } \\
\text { standard } \\
\text { deviation }\end{array}$ & $\begin{array}{c}\text { Between } \\
\text { standard } \\
\text { deviation }\end{array}$ & $\begin{array}{c}\text { Within } \\
\text { standard } \\
\text { deviation }\end{array}$ \\
\hline $\begin{array}{l}\text { Wealth Gini } \\
(146 \text { countries, 2010-2014) }\end{array}$ & 71.07 & 44.70 & 100 & 6.96 & 6.15 & 3.41 \\
$\begin{array}{l}\text { Income Gini } \\
(154 \text { countries, 1990-2014) }\end{array}$ & 44.95 & 18.05 & 76.39 & 7.60 & 7.04 & 3.43 \\
\hline
\end{tabular}

Source: Author's own elaboration on the basis of SWIID and the Credit Swiss Reports.

In the following, three scatterplots are presented: income Gini vs wealth Gini (period 2010-2014, 116 countries), income Gini vs real growth of GDP per capita (period 2010-2014, 146 countries) and wealth Gini vs real growth of GDP per capita (period 1990-2014, 154 countries). For each inequality measure, we report a scatterplot of inequality vs real per capita GDP growth with reference to the largest sample available.

Figure 1 provides some indication of the existence of a positive relationship between income and wealth inequality. However, the two inequality measures are not always closely associated and it is possible to identify several points which are very far from the $45^{\circ}$ line. For example, in Kazakhstan, the income Gini coefficient is equal to about 30, whereas the wealth Gini coefficient is greater than 80 .

In Figure 2.1, the outlier in the lower part of the graph is the Central African Republic, which in 2013 recorded a growth rate of its real per capita GDP equal to $-37.3 \%$. This was largely due to the outbreak of a civil war in the country. On the other hand, there were some countries which reported very high growth rates of real per capita GDP. For example, Sierra Leone had growth rates higher than $10 \%$ in both $2012(+12.7 \%)$ and $2013(+18.3 \%) .{ }^{3}$ Moreover, Mongolia

3 It is worth noting here that, in 2012, with the technical assistance of the International Monetary Fund, Sierra Leone changed the base year for the computation of real GDP from 2001 to 2006 , in order to comply with international standards. This accounts, at least partially, for the very large rate of real per capita GDP growth that was recorded in years 2012 and in 2013. 
Figure 1: Scatterplot of Wealth Gini vs Income Gini, 116 Countries, 2010-2014

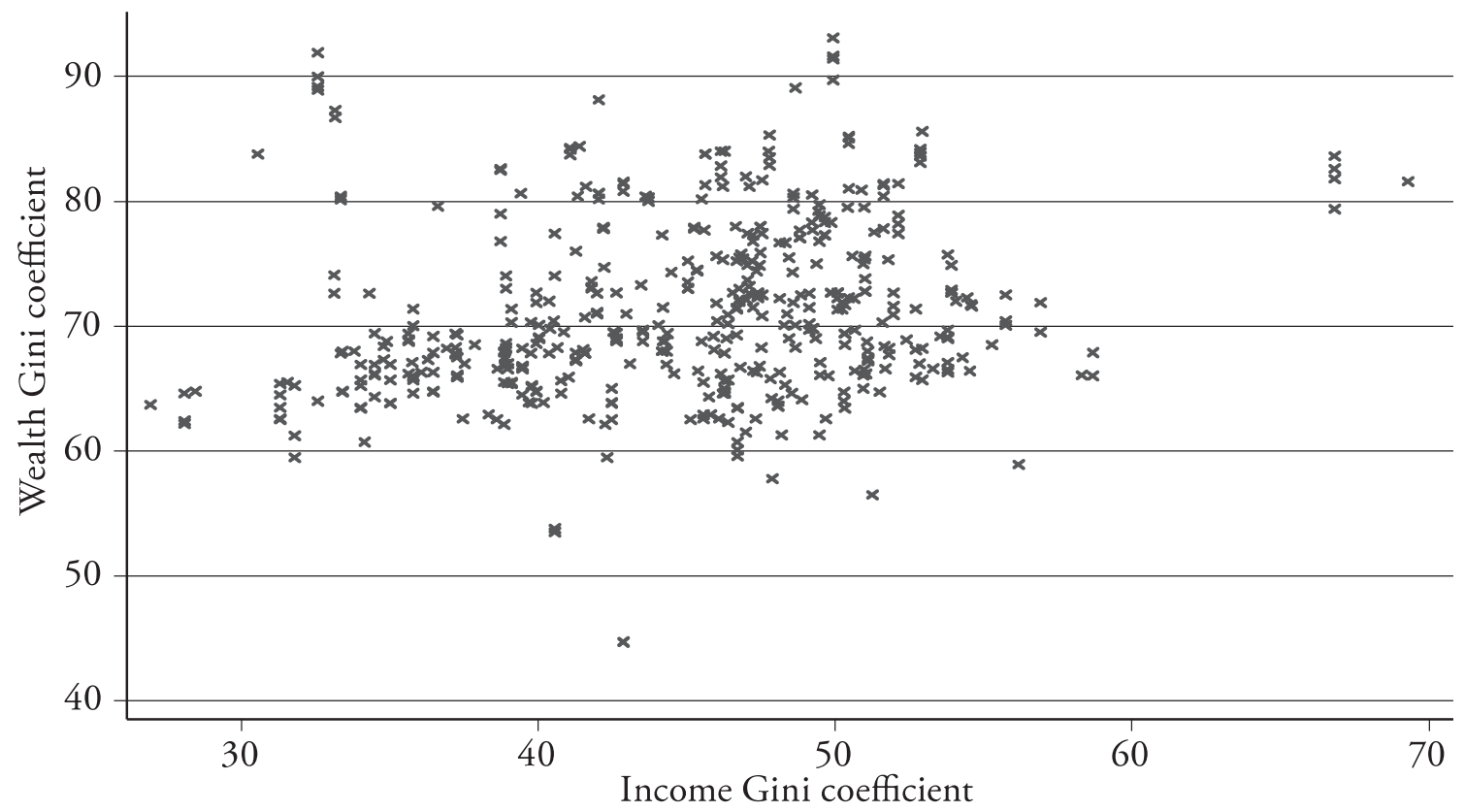

Yearly data (not averaged over the time period considered).

Source: Author's own elaboration on the basis of SWIID and the Credit Swiss Reports.

Figure 2.1: Scatterplot of Wealth Gini vs GDP Real Per Capita Annual Growth,

146 Countries, 2010-2014

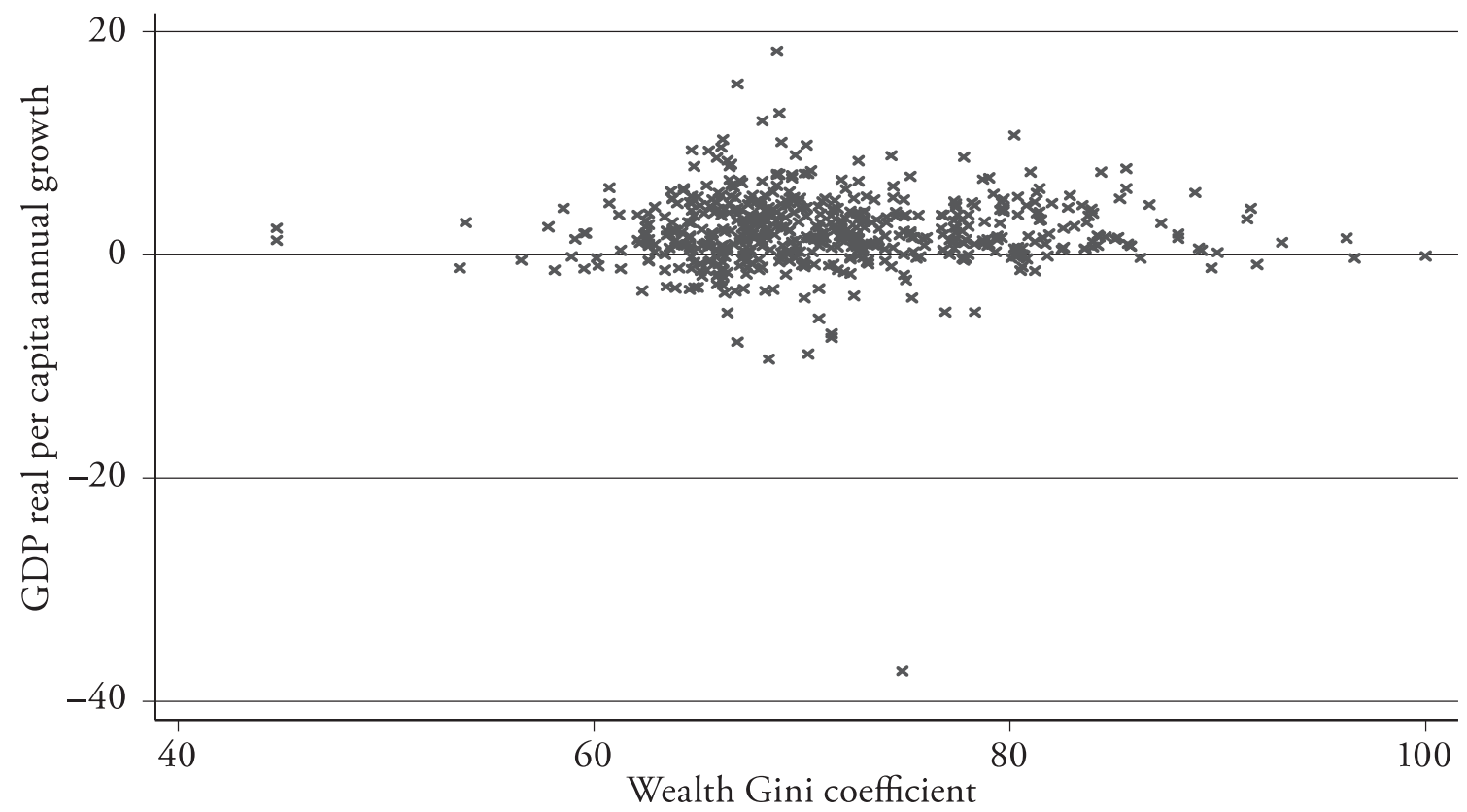

Yearly data (not averaged over the time period considered).

Source: Author's own elaboration on the basis of World Bank (WB) data and the Credit Swiss Reports. 
Figure 2.2: Scatterplot of Income Gini vs GDP Real Per Capita Annual Growth, 154 Countries, 1990-2014

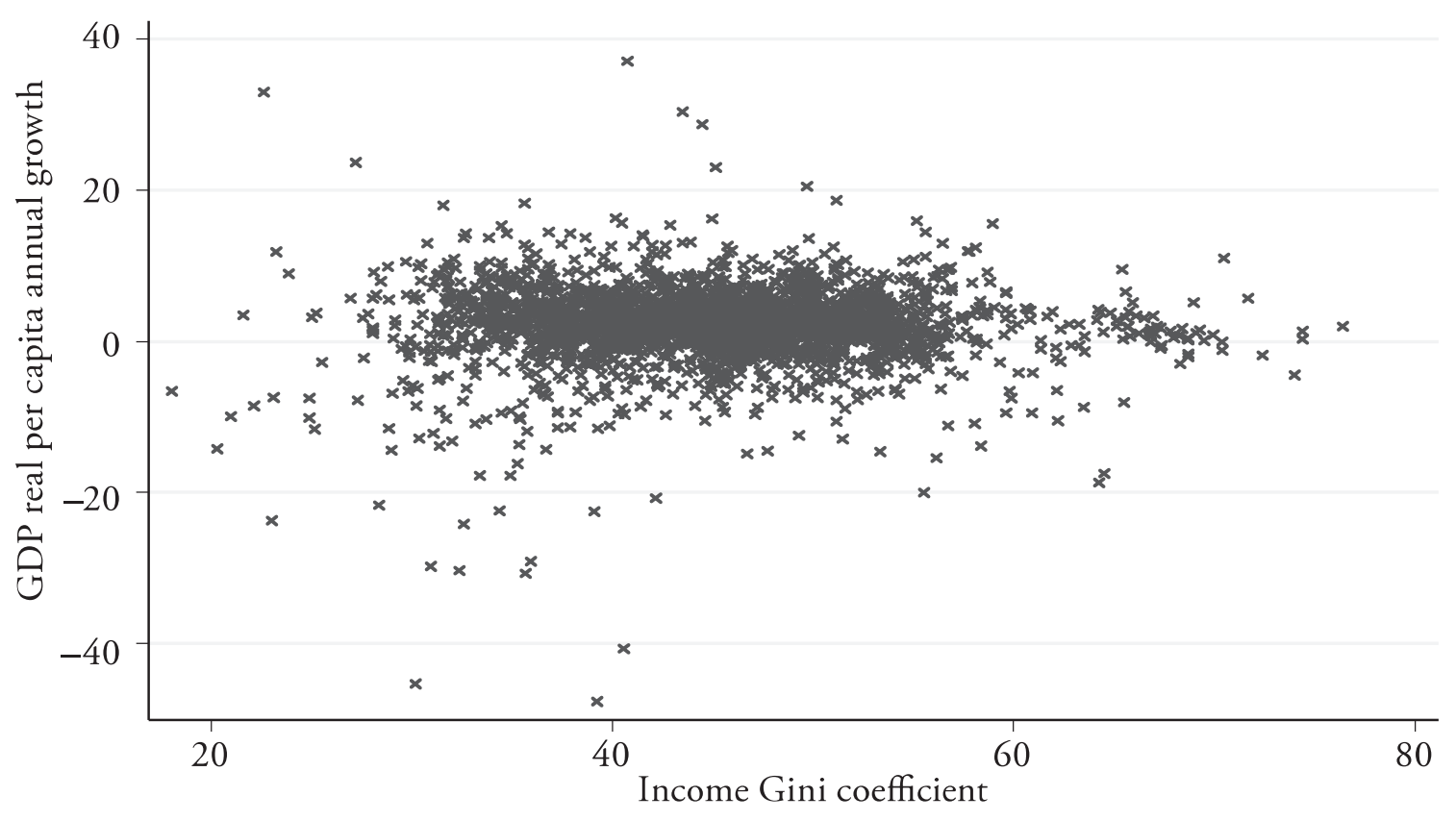

Yearly data (not averaged over the time period considered).

Source: author's own elaboration on the basis of WB and SWIID data.

reported a growth rate of its real per capita GDP equal to $+15.3 \%$ in 2011 and to +10.3 in 2012 . $^{4}$

As for Figure 2.2, we first notice that there is a large degree of dispersion in the annual GDP per capita growth rates; this seems reasonable, since this extended sample covers a large number of countries and years (154 countries for 25 years). Therefore, data on annual per capita real GDP in this sample show large fluctuations, which may be due, for example, to wars or radical changes in the economic structure of a country (e.g. transition economies). Just to mention some examples, in 1992 Armenia, Georgia and Tajikistan recorded growth rates of real per capita GDP that were equal, respectively, to $-40.7 \%,-45.3 \%$ and $-30.6 \%$. On the other hand, some countries experienced very high growth rates. Just to mention two of them, in 2004 Chad witnessed growth rates of real per capita GDP equal to around $+30 \%$ and in 2006 Azerbaijan had a growth rate of real per capita GDP of about $+30 \%$, too.

4 Mongolia's fast economic growth is mainly due to the presence of large deposits of coal, copper, gold and uranium on its territory. Just to take an example, more than $3 \%$ of the world's copper is produced in Mongolia. 
From Figures 2.1 and 2.2 we can immediately assess that there is no evident relationship between income inequality and real GDP per capita growth. Similarly, it is also possible to deduce from the scatterplots that there is no straightforward relationship between wealth inequality and real GDP per capita growth. Data show a large dispersion and the relationship of interest is likely to be nonlinear.

We now compute some dependence measures between income Gini and wealth Gini and between both inequality measures and GDP per capita growth. The results, which are reported in Table 3, show a rather weak correlation between income Gini and wealth Gini. The two indices do not seem to have a high degree of co-movement. There is some indication that there could be a negative relationship between income inequality and GDP per capita growth; however, the degree of co-movement seems to be low. Moreover, there seems to be a positive, but weak, relationship between wealth inequality and GDP per capita growth. These results deserve further investigation with econometric techniques.

Table 3: Dependence Measures between Income Gini and Wealth Gini, between Income Gini and Real GDP Per Capita Growth, and between Wealth Gini and Real GDP Per Capita Growth

\begin{tabular}{lccc}
\hline & Correlation & Kendall's Tau & Spearman's Rho \\
\hline $\begin{array}{l}\text { Income and wealth Gini } \\
(116 \text { countries, 2010-2014) }\end{array}$ & 0.23 & 0.18 & 0.27 \\
$\begin{array}{l}\text { Wealth Gini and GDP per capita growth } \\
(146 \text { countries, 2010-2014) }\end{array}$ & 0.03 & 0.04 & 0.07 \\
$\begin{array}{l}\text { Income Gini and GDP per capita growth } \\
(154 \text { countries, 1990-2014) }\end{array}$ & 0.01 & -0.04 & -0.06 \\
\hline
\end{tabular}

Source: Author's own elaboration on the basis of WB data, SWIID data and the Credit Swiss Reports. 


\subsection{The Model}

We propose the following model for estimation. This is obtained by adding the squared Gini term and the interaction terms to the baseline model used by FORBES (2000):

$$
\begin{aligned}
\text { Growth }_{i, t} & =\beta_{0}+\beta_{1} \text { Gini }_{i, t}+\beta_{2} \text { Income }_{i, t-1}+\beta_{3} E_{d u_{i, t}}+\beta_{4} P P P_{i, t} \\
& +\beta_{5} \text { Gini }_{i, t}^{2}+\beta_{6} \text { Gini }_{i, t} * \text { Income }_{i, t-1}+\beta_{7} \text { Gini }_{i, t} * \text { Edu }_{(i, t)} \\
& +\beta_{8} \text { Gini }_{i, t} * P P P_{i, t}+\text { continent dummies } \\
& + \text { year dummies }+\alpha_{i}+\eta_{t}+v_{i, t}
\end{aligned}
$$

In the above-presented equation, the subscript $i$ represents the country and $t$ stands for the time; $\alpha_{i}$ are country-fixed effects, $\eta_{i}$ are year dummies and the $v_{i, t}$ stand for the error terms. The marginal effect of $\Delta G_{i n i} i_{i, t}$ on Growth $_{i, t}$ can be expressed as follows:

$$
\frac{\partial E\left[\text { Growth }_{i, t}\right]}{\partial \Delta \text { Gini }_{i, t}}=\beta_{1}+2 \beta_{5} \text { Gini }_{i, t}+\beta_{6} \text { Income }_{i, t-1}+\beta_{7} E d u_{i, t}+\beta_{8} P_{P P} P_{i, t}
$$

Table 4 contains the definition of the explanatory variables employed, as well as some descriptive statistics for the period 2010-2014. Data for all explanatory variables, except the Gini coefficient, are taken from the latest release of World Development Indicators, published by the World Bank (WB, 24 September 2015).

Furthermore, in equation (1) $\mathrm{Gini}_{i, t}{ }^{2}$ is the squared Gini term, Gini $i_{i, t} * \operatorname{Income}_{i, t-1}$ is the interaction term between the Gini coefficient and the lagged level of real per capita GDP, Gini $i_{i, t} * E d u_{i, t}$ is the interaction term between the Gini coefficient and the education variable and $\operatorname{Gini}_{i, t} * P P P_{i, t}$ stands for the interaction term between the Gini coefficient and the PPP variable.

An issue that arises in the estimation of the above-presented model is that of reverse causality or endogeneity. Endogeneity may be present due to omittedvariable bias, measurement error or simultaneity. On the one hand, the presence of omitted variables cannot be excluded; on the other hand, measurement error is minimized, thanks to the high quality of the data used.

The issue of simultaneity deserves to be analyzed in detail. We aim at estimating, indeed, the impact of inequality on GDP per capita growth; however, from an economic viewpoint, it is plausible that the level of development reached by a country has an influence, in turn, on the domestic inequality level. 
Table 4: Definition and Descriptive Statistics of the Explanatory Variables, 146 Countries, 2010-2014

\begin{tabular}{|c|c|c|c|c|c|}
\hline Variable & Definition & Mean & $\begin{array}{l}\text { Standard } \\
\text { deviation }\end{array}$ & Min & Max \\
\hline $\begin{array}{l}\text { Initial per } \\
\text { capita GDP } \\
\left(\text { Income }_{i, t-1}\right)\end{array}$ & $\begin{array}{l}\text { This is the one-year lagged level } \\
\text { of real per capita GDP (i.e. gross } \\
\text { domestic product divided by } \\
\text { midyear population, expressed } \\
\text { in constant } 2005 \text { US\$). }{ }^{2} \text { In the } \\
\text { estimating equation, the logarithm } \\
\text { of this variable is employed. }\end{array}$ & $13^{\prime} 107.18$ & $16 ' 871.56$ & 196.86 & $82^{\prime} 656.02$ \\
\hline $\begin{array}{l}\text { Education } \\
\left(E d u_{i, t}\right)\end{array}$ & $\begin{array}{l}\text { Gross secondary enrollment ratio } \\
\text { computed by the World Bank. This } \\
\text { variable stands for total enrollment } \\
\text { in secondary education, regardless } \\
\text { of age, expressed as a percentage of } \\
\text { the population of official secondary } \\
\text { education age. It can exceed } 100 \% \\
\text { due to the inclusion of over-aged } \\
\text { and under-aged students because } \\
\text { of early or late school entrance and } \\
\text { grade repetition. }\end{array}$ & 87.10 & 25.07 & 17.79 & 165.58 \\
\hline $\operatorname{PPP}\left(P P P_{i, t}\right)$ & $\begin{array}{l}\text { This is the ratio of PPP conversion } \\
\text { factor to market exchange rate. }\end{array}$ & 0.66 & 0.30 & 0.25 & 1.61 \\
\hline
\end{tabular}

a Note that in all the equations presented the lagged income variable is defined as the log of the initial real per capita GDP. However, in Table 4, summary statistics are on initial real per capital GDP (without considering the log), since they are more meaningful from an economic viewpoint.

b This variable has been preferred to the net secondary enrollment ratio, i.e. the total number of students in the theoretical age group for secondary education enrolled in that level, expressed as a percentage of the total population in that age group, due to a greater data availability for the gross enrollment indicator.

Source: Author's own elaboration on the basis of WB data.

As mentioned in section 2, this direction of research was first explored by Kuznets (1955). According to Kuznets' hypothesis, inequality first rises and then declines as an economy goes through the different stages of development. Even though this theory has been challenged by several empirical studies, the possibility of reverse causality cannot be excluded and therefore it will be taken into account in the formulation of the estimation strategy. 
The variables relative to secondary school enrollment may suffer from endogeneity, too. It is reasonable, indeed, to suppose that the level of development reached by a country plays an important role in determining the availability and the quality of secondary schools and the opportunities for pupils to attend them. According to Saint-Paul and Verdier (1993) and Forbes (2000), economic growth may free resources to be invested in the process of human capital accumulation. Thus, GDP growth may cause a rise in education levels and variables relative to education may be endogenous.

With reference to the PPP variable, it is defined by the World Bank as the purchasing power parity conversion factor (i.e. the GDP deflator) divided by the market exchange rate. This variable may, of course, be influenced by the domestic rate of growth; however, under the hypothesis that each country is relatively small with respect to the world economy, this variable can be reasonably considered as exogenous, since it will be influenced by the economic performance of all other countries as well. FORBEs (2000) employs a similar variable, the price level of investment, which is defined as the PPP of investment divided by the exchange rate. The author argues that this variable is exogenous and therefore it does not need to be instrumented.

Some authors use lagged values of the control variables to reduce reverse causality problems. KeEFER and KNACK (2002) consider the average annual growth rate of per capita income over the period 1970-1992 as the dependent variable and employ data relative to human capital and inequality relative to 1980 or earlier, in order to minimize the risk of reverse causation. Fallah and PARTRIdge (2007), too, employ observations of their explanatory variables relative to the year 1989-90, in order to analyze the determinants of growth over the period 1990-2000. However, introducing one-year lagged data for the endogenous variables in our model would not be enough to solve the endogeneity issues. The lagged value of an endogenous variable, in fact, is influenced by the lagged value of economic growth.

Since past economic growth is likely to be correlated with present economic growth, the lagged value of the covariate would be, in turn, correlated with current growth, thus still being endogenously determined.

According to Mo (2000), the use of Gini coefficient data measured at the beginning of the period considered, or even before, may not be enough to solve the problem of reverse causality between inequality and GDP growth rate. We have tried to run some IV estimates with traditional instruments, such as fertility

5 Furthermore, solutions like the introduction in the model of five-year or even ten-year lagged data for the control variables would excessively reduce the sample size. 
rate, government consumption expenditure or investment ratio (BARRO and SALAI-MARTIN 2003). However, the results were rarely statistically significant, and in most cases first-stage statistics did not confirm the validity of the instruments used. Therefore, in the present paper, the Arellano-Bond GMM estimation technique has been preferred to the IV technique, in order to tackle the endogeneity issue of the Gini as well as of the other controls.

A relevant feature of the model presented, in fact, is its dynamic nature. Equation (1), indeed, contains a lagged endogenous variable, which is the lagged real per capita income. Real GDP per capita growth, in fact, can be expressed as the difference of the logarithms of the present and past real per capita income levels:

$$
\begin{aligned}
\text { Growth }_{i, t} & =\ln \left(\frac{\text { Income }_{i, t}}{\text { Income }_{i, t-1}}\right)=\ln \left(\text { Income }_{i, t}\right)-\ln \left(\text { Income }_{i, t-1}\right) \\
& =\Delta \ln \left(\text { Income }_{i, t}\right)
\end{aligned}
$$

It is known that the estimation of a dynamic model by Ordinary Least Squares (OLS), Fixed Effects (FE) or Random Effects (RE) yields biased results. Several empirical strategies have been proposed in the literature to instrument the lagged dependent variable. In the present paper, we apply the Generalized Method of Moments developed by Arellano and Bond (1991), who use lagged levels dated $t-2$ and earlier for the equation in first-differences. This difference-GMM estimator computes the first-differences of each variable, in order to eliminate country-specific effects. Equation (1) is thus rewritten as it follows:

$$
\begin{aligned}
\Delta \ln \left(\text { Income }_{i, t}\right)= & \gamma \Delta \ln \left(\text { Income }_{i, t-1}\right)+\beta_{1} \Delta \operatorname{Gini}_{i, t}+\beta_{3} \Delta E d u_{i, t} \\
& +\beta_{4} \Delta P P P_{i, t}+\beta_{5} \Delta \text { Gini }_{i, t}^{2}+\beta_{6} \Delta \text { Gini }_{i, t} * \text { Income }_{i, t-1} \\
& +\beta_{7} \Delta \operatorname{Gini}_{i, t} * E d u_{i, t}+\beta_{8} \Delta \operatorname{Gini}_{i, t} * P P P_{i, t}
\end{aligned}
$$

In period $3, \ln \left(\right.$ Income $\left._{i, 1}\right)$ is used as an instrument for $\ln \left(\right.$ Income $\left._{i, 2}\right)-\ln \left(\right.$ Income $\left._{i, 1}\right)$, whereas in period 4 both $\ln \left(\right.$ Income $\left._{i, 1}\right)$ and $\ln \left(\right.$ Income $\left._{i, 2}\right)$ are used as instruments for $\ln \left(\right.$ Income $\left._{i, 3}\right)-\ln \left(\right.$ Income $\left._{i, 2}\right)$ and so on. The same procedure is applied in order to create instruments for each of the differenced variables. The necessity to use values lagged at least two times as instruments leads to the elimination from the sample of countries for which only two consecutive observations were available. However, first differencing introduces a correlation between the error term $\Delta v_{i, t}$ and the differenced lagged dependent variable, $\Delta \ln \left(\right.$ Income $\left._{i,-1-1}\right)$. An OLS estimation in this case would produce biased results, even if the other explanatory 
variables were strictly exogenous. Therefore, instrumental variables are used for the equations in first differences (ARELlano and Bond, 1991).

Consistency of the GMM estimator depends on the validity of the instruments used. In order to asses it, the Hansen test on the overall validity of the instruments will be performed. We will also test the presence of serial correlation in the residuals. Many alternative specifications of the model have been estimated, in order to perform some robustness checks. The estimation results are presented in the following section.

\section{Estimation Results}

\subsection{Some Preliminary (Biased) Results}

As a first step, we perform some preliminary OLS estimates, in order to check whether there is an evident relationship between inequality and growth. ${ }^{6}$ Many alternative model specifications have been estimated with OLS. The main results are reported here. In general, the relationship between wealth inequality and real per capita GDP growth seems not to be robust to alternative model formulations.

In our OLS estimates, the wealth Gini coefficient is statistically insignificant in all model specifications (i.e. with and without year and continent dummies, with and without the squared Gini term and the interaction terms). We notice some evidence of a negative impact of the initial level of real per capita GDP on the rate of GDP per capita growth, as well as some indications of a negative relationship between the PPP variable and the real GDP per capita growth. However, the other explanatory variables are also rarely significant, thus suggesting a potential model misspecification. The interaction terms, too, are hardly statistically significant. We conclude that OLS results are biased and we resort to other estimation techniques.

As for Fixed Effects (FE) and Random Effects (RE) techniques, equation (3) in Table 5 provides us with a hint of the existence of a negative relationship between wealth Gini and real per capita GDP growth. However, this relationship is not robust to the inclusion of the squared wealth Gini term and that of the interaction terms in the model. Again, we get some indication of the presence of a negative relationship between the initial level of real per capita GDP and the subsequent annual rate of growth of real per capita GDP.

6 Please note that in this section, whenever we refer to growth or growth rate, we mean "real GDP per capita annual growth rate". 
Table 5: Impact of Income and Wealth Gini on GDP Per Capita Growth -

OLS, FE and RE Estimates, 146 countries

\begin{tabular}{|c|c|c|c|c|c|c|c|c|c|}
\hline Variable & \multicolumn{2}{|c|}{$\begin{array}{c}\text { (1) OLS, } \\
2010-2014, \\
\text { wealth Gini, model } \\
\text { with continent } \\
\text { dummies and time } \\
\text { dummies. }\end{array}$} & \multicolumn{2}{|c|}{$\begin{array}{c}\text { (2) OLS, } \\
\text { 2010-2014, } \\
\text { wealth Gini, model } \\
\text { with continent } \\
\text { dummies and time } \\
\text { dummies, with } \\
\text { Gini squared and } \\
\text { interaction terms. }\end{array}$} & $\begin{array}{l}\text { (3) FE, } \\
\text { 2010-2014, } \\
\text { wealth Gini, } \\
\text { model with time } \\
\text { dummies. }\end{array}$ & $\begin{array}{c}\text { (4) RE, } \\
2010-2014 \text {, } \\
\text { wealth Gini, model } \\
\text { with continent } \\
\text { dummies and time } \\
\text { dummies. }\end{array}$ & $\begin{array}{c}\text { (5) FE, } \\
\text { 2010-2014, } \\
\text { wealth Gini, } \\
\text { model with time } \\
\text { dummies, Gini } \\
\text { squared and } \\
\text { interaction terms. }\end{array}$ & \multicolumn{2}{|c|}{$\begin{array}{c}\text { (6) RE, } \\
\text { 2010-2014, } \\
\text { wealth Gini, model } \\
\text { with continent } \\
\text { dummies, time } \\
\text { dummies, Gini } \\
\text { squared and } \\
\text { interaction terms. }\end{array}$} \\
\hline Initial income & $-0.47^{* *}$ & $(0.21)$ & $-3.51^{*}$ & $(1.97)$ & $-24.64^{* * *}(2.70)$ & $-0.56^{*} \quad(0.30)$ & $-28.81^{* * *}(4.16)$ & -3.15 & $(2.36)$ \\
\hline Wealth Gini & 0.02 & $(0.02)$ & -0.10 & $(0.33)$ & $-0.06^{*} \quad(0.03)$ & $0.001 \quad(0.03)$ & $-0.74 \quad(0.47)$ & -0.16 & $(0.36)$ \\
\hline Edu & 0.01 & $(0.01)$ & 0.09 & $(0.10)$ & $-0.02 \quad(0.03)$ & $0.02 \quad(0.01)$ & $-0.11 \quad(0.14)$ & 0.03 & $(0.11)$ \\
\hline $\mathrm{PPP}$ & $-1.43^{*}$ & $(0.80)$ & 2.85 & $(7.58)$ & $-0.03 \quad(3.57)$ & $-1.21 \quad(1.16)$ & $10.67 \quad(12.77)$ & 2.01 & (9.33) \\
\hline $\begin{array}{l}\text { Squared wealth } \\
\text { Gini }\end{array}$ & - & & -0.001 & $(0.002)$ & - & - & $0.001 \quad(0.002)$ & -0.001 & $(0.002)$ \\
\hline Init. income $*$ Gini & - & & 0.04 & $(0.03)$ & - & - & $0.06 \quad(0.04)$ & 0.04 & $(0.03)$ \\
\hline Edu $*$ Gini & - & & -0.001 & $(0.001)$ & - & - & $0.001 \quad(0.002)$ & -0.0001 & $(0.002)$ \\
\hline $\mathrm{PPP} * \mathrm{Gini}$ & 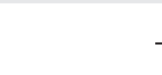 & & -0.06 & $(0.11)$ & - & - & $-0.15 \quad(0.18)$ & -0.05 & $(0.13)$ \\
\hline Asia & 0.46 & $(0.44)$ & 0.36 & $(0.45)$ & - & $0.44 \quad(0.67)$ & - & 0.37 & $(0.69)$ \\
\hline Africa & -0.07 & $(0.54)$ & -0.11 & $(0.55)$ & - & $-0.15 \quad(0.84)$ & - & -0.16 & $(0.85)$ \\
\hline
\end{tabular}




\begin{tabular}{|c|c|c|c|c|c|c|c|c|c|c|}
\hline \multirow[t]{2}{*}{$\begin{array}{l}\text { Variable } \\
\\
\text { America }\end{array}$} & \multicolumn{2}{|c|}{$\begin{array}{c}\text { (1) OLS, } \\
\text { 2010-2014, } \\
\text { wealth Gini, model } \\
\text { with continent } \\
\text { dummies and time } \\
\text { dummies. }\end{array}$} & \multicolumn{2}{|c|}{$\begin{array}{c}\text { (2) OLS, } \\
\text { 2010-2014, } \\
\text { wealth Gini, model } \\
\text { with continent } \\
\text { dummies and time } \\
\text { dummies, with } \\
\text { Gini squared and } \\
\text { interaction terms. }\end{array}$} & \multirow[t]{2}{*}{$\begin{array}{l}\text { (3) FE, } \\
\text { 2010-2014, } \\
\text { wealth Gini, } \\
\text { model with time } \\
\text { dummies. } \\
-\end{array}$} & \multicolumn{2}{|c|}{$\begin{array}{c}\text { (4) RE, } \\
\text { 2010-2014, } \\
\text { wealth Gini, model } \\
\text { with continent } \\
\text { dummies and time } \\
\text { dummies. }\end{array}$} & \multirow[t]{2}{*}{$\begin{array}{c}\text { (5) FE, } \\
\text { 2010-2014, } \\
\text { wealth Gini, } \\
\text { model with time } \\
\text { dummies, Gini } \\
\text { squared and } \\
\text { interaction terms. } \\
-\end{array}$} & \multicolumn{2}{|c|}{$\begin{array}{c}\text { (6) RE, } \\
2010-2014 \text {, } \\
\text { wealth Gini, model } \\
\text { with continent } \\
\text { dummies, time } \\
\text { dummies, Gini } \\
\text { squared and } \\
\text { interaction terms. }\end{array}$} \\
\hline & 0.41 & $(0.42)$ & 0.34 & $(0.44)$ & & 0.41 & $(0.65)$ & & 0.38 & $(0.67)$ \\
\hline 2010 & $0.74^{*}$ & $(0.44)$ & $0.77^{*}$ & $(0.45)$ & $-1.47^{* * *}(0.44)$ & $0.69^{*}$ & $(0.38)$ & $-1.28^{* * *}(0.45)$ & $0.76^{* *}$ & $(0.39)$ \\
\hline 2011 & 0.36 & $(0.43)$ & 0.39 & $(0.43)$ & $-1.03^{* * *}(0.40)$ & 0.42 & $(0.36)$ & $-0.88^{* * *}(0.41)$ & 0.47 & $(0.37)$ \\
\hline 2012 & -0.18 & $(0.42)$ & -0.16 & $(0.42)$ & $-1.04^{* * *}(0.36)$ & -0.14 & $(0.36)$ & $-0.96^{* * *}(0.36)$ & -0.11 & $(0.36)$ \\
\hline 2013 & -0.31 & $(0.42)$ & -0.29 & $(0.42)$ & $-0.79^{* * *}(0.34)$ & -0.31 & $(0.35)$ & $-0.75^{* * *}(0.34)$ & -0.28 & $(0.35)$ \\
\hline R-sq & 0.05 & & 0.05 & & 0.16 & 0.02 & & 0.16 & 0.03 & \\
\hline P-value F-test & 0.00 & & 0.00 & & 0.00 & & & 0.00 & - & \\
\hline $\begin{array}{l}\text { P-value of the } \\
\text { Wald test }\end{array}$ & & & & & - & 0.00 & & - & 0.01 & \\
\hline N. of countries & 146 & & 146 & & 146 & 146 & & 146 & 146 & \\
\hline N. of obs. & 673 & & 673 & & 673 & 673 & & 673 & 673 & \\
\hline
\end{tabular}

Notes. The dependent variable is real GDP per capita growth in all the equations. Europe is the omitted attribute among the continent dummies and year 2014 is the omitted attribute among the year dummies. In equations (1)-(2), R-sq stands for adjusted R-squared. In regressions (3)-(6), standard errors are clustered on countries and R-sq reported is within. Source: Author's own elaboration. 
Table 6: Impact of wealth Gini on real GDP per capita growth - Arellano-Bond GMM estimates

\begin{tabular}{|c|c|c|c|c|c|c|c|c|}
\hline Variable & \multicolumn{2}{|c|}{$\begin{array}{l}\text { (7) Arellano-Bond } \\
\text { GMM two-step, } \\
\text { wealth Gini, } \\
146 \text { countries }\end{array}$} & \multicolumn{2}{|c|}{$\begin{array}{l}\text { (8) Arellano-Bond } \\
\text { GMM two-step, } \\
\text { wealth Gini, with continent } \\
\text { dummies, } 146 \text { countries }\end{array}$} & \multicolumn{2}{|c|}{$\begin{array}{l}\text { (9) Arellano-Bond } \\
\text { GMM two-step, } \\
\text { wealth Gini, with squared } \\
\text { Gini term, } 146 \text { countries }\end{array}$} & \multicolumn{2}{|c|}{$\begin{array}{c}\text { (10) Arellano-Bond } \\
\text { GMM two-step, } \\
\text { wealth Gini, with interaction } \\
\text { terms, } 146 \text { countries }\end{array}$} \\
\hline Initial income & -0.05 & $(0.77)$ & 0.71 & $(0.63)$ & -0.31 & $(0.71)$ & -0.16 & $(4.24)$ \\
\hline Wealth Gini & $0.11^{*}$ & $(0.06)$ & 0.07 & $(0.05)$ & $0.23^{* * *}$ & $(0.09)$ & $0.15^{* *}$ & $(0.07)$ \\
\hline Edu & $-0.07^{* *}$ & $(0.03)$ & $-0.07^{* *}$ & $(0.03)$ & $-0.05^{*}$ & $(0.03)$ & 0.10 & $(0.40)$ \\
\hline PPP & 0.48 & $(3.51)$ & -3.33 & $(2.39)$ & -0.26 & $(3.30)$ & -15.48 & $(27.50)$ \\
\hline Squared Gini & \multicolumn{2}{|l|}{-} & \multicolumn{2}{|l|}{-} & $-0.001^{*}$ & $(0.001)$ & \multicolumn{2}{|l|}{-} \\
\hline Init. income $*$ Gini & \multicolumn{2}{|c|}{-} & \multicolumn{2}{|l|}{-} & \multicolumn{2}{|l|}{-} & -0.01 & $(0.06)$ \\
\hline $\mathrm{Edu} * \mathrm{Gini}$ & \multicolumn{2}{|c|}{-} & \multicolumn{2}{|l|}{-} & \multicolumn{2}{|l|}{-} & -0.002 & $(0.01)$ \\
\hline PPP * Gini & \multicolumn{2}{|c|}{-} & \multicolumn{2}{|l|}{-} & \multicolumn{2}{|l|}{-} & 0.22 & $(0.38)$ \\
\hline Asia & \multicolumn{2}{|l|}{-} & $-1.60^{* *}$ & $(0.67)$ & \multicolumn{2}{|l|}{-} & \multicolumn{2}{|c|}{-} \\
\hline Africa & \multicolumn{2}{|l|}{-} & $-2.68^{* *}$ & $(1.08)$ & \multicolumn{2}{|l|}{-} & \multicolumn{2}{|c|}{-} \\
\hline America & \multicolumn{2}{|l|}{-} & -0.99 & $(0.71)$ & \multicolumn{2}{|l|}{-} & \multicolumn{2}{|c|}{-} \\
\hline $\begin{array}{l}\text { P-value Cumby- } \\
\text { Huizinga test (lag 1) }\end{array}$ & \multicolumn{2}{|l|}{1.00} & \multicolumn{2}{|l|}{1.00} & \multicolumn{2}{|l|}{1.00} & \multicolumn{2}{|l|}{1.00} \\
\hline $\begin{array}{l}\text { P-value Cumby- } \\
\text { Huizinga test (lag 2) }\end{array}$ & \multicolumn{2}{|l|}{1.00} & \multicolumn{2}{|l|}{1.00} & \multicolumn{2}{|l|}{1.00} & \multicolumn{2}{|l|}{1.00} \\
\hline P-value Hansen Test & \multicolumn{2}{|l|}{0.63} & \multicolumn{2}{|l|}{0.10} & \multicolumn{2}{|l|}{0.81} & \multicolumn{2}{|l|}{0.62} \\
\hline N. of obs. & 381 & & 381 & & 381 & & 381 & \\
\hline
\end{tabular}


In addition, time dummies are often statistically significant and they hint at the presence of a somewhat positive time trend (with the exception of year 2012) in the annual growth rate of real per capita GDP. However, as explained before, in a dynamic context both Fixed Effect and Random Effects estimates are biased and inconsistent. Therefore, the results presented in Table 5 have to be considered with caution. We now turn to the Arellano-Bond GMM estimation method, in order to eliminate the Nickell bias.

\subsection{Arellano-Bond GMM Estimation Results}

As for the results reported in Table 6, when the estimated coefficient of the wealth Gini is statistically significant, it is always positive, thus suggesting that there may be a positive relationship between wealth inequality and growth rate of real per capita GDP. The size of our estimated coefficient ranges between 0.11 and 0.23 .

This result is notably larger than that obtained by ForBes in 2000 (0.0013); however, the results obtained by GrIJALVA (2011) for the medium term (10-year averages) are even greater than ours. Grijalva (2011) finds, in fact, that income inequality has a positive and statistically significant impact on growth. In Grijalva's estimation results, in fact, the size of the estimated coefficient of income inequality ranges between 0.28 and 1.30 .

Going back to our estimation results (Table 6), when the coefficient of the squared Gini term is statistically significant, it is always negative. Equation (9) in Table 6 suggests that the shape of the relationship between income inequality and growth takes the form of an inverted $U$. This finding is in accordance with Chen (2003), who finds evidence of an inverted-U relationship between inequality and growth in the long term (he considers the period 1970-1992). This means that, at low inequality levels, there is a positive relationship between the wealth Gini coefficient and the real rate of per capita GDP growth. On the contrary, after a certain threshold value of the Gini coefficient is reached, wealth inequality is negatively associated with the real growth rate of per capita GDP.

$\leftarrow$ Notes to Table 6: The dependent variable is real GDP per capita growth in all model estimates. Standard errors are robust to heteroskedasticity and clustered on countries. In all model specifications the following variables are considered endogenous and thus instrumented: initial income, wealth Gini, education and, when present in the estimating equation, also the squared Gini term and the three interaction terms between Gini and the other explanatory variables (Initial Income* Gini, Education $*$ Gini and $P P P *$ Gini).

Source: Author's own elaboration. 
The inverted-U shape implies that extreme values (in both directions) of the Gini coefficient negatively affect growth. This would imply that either very high or very low values of the income Gini coefficient are associated with high GDP per capita growth rates. Perhaps very high-income inequality levels are necessary in order to stimulate savings and investments, whereas very low inequality levels stimulate growth through the channels of cooperation and social cohesion. We find here some empirical support for the claim that the relationship between inequality and growth has a nonlinear nature, as suggested by BANERJEE and Duflo (2003) and Knowles (2005).

The coefficient for the squared inequality term obtained by GriJALVA (2011) is negative and statistically significant, as in our estimates; in particular, the values reported by Grijalva range between -0.32 and -1.58 , i.e. they are larger in absolute value than our estimates. In fact, we get a value for the coefficient of the squared Gini term of about -.0013 . With reference to equation (9) reported in Table 6, the optimal wealth inequality level in this context should correspond to a value of the wealth Gini coefficient equal to about 87 (out of 100), i.e. the optimal wealth inequality level appears to be rather high.

For example, let us consider the case of Kyrgyzstan in year 2013. On the basis of equation (9) in Table 6, if the wealth Gini coefficient were to rise from 65.9 to 66.9, then the GDP per capita growth rate (which in 2013 was equal to $8.74 \%$ ), would increase by around 0.055 percentage points.

On the other hand, if we look at the case of Germany in the same year, if the wealth Gini coefficient were to rise from 68.4 to 69.4, then, on the basis of equation (9), the real growth rate of per capita GDP (which in 2013 was equal to $0.02 \%$ ), would increase by about 0.048 percentage points.

This positive effect of a rise in wealth inequality can be explained by resorting to the investment channel of transmission: higher wealth concentration allows some people to realize large investments. These investments enhance productivity and therefore economic growth. This result contrasts with Deininger and Olinto (1999). The authors find, in fact, evidence of a negative relationship between wealth inequality and growth. However, they use the land Gini coefficient as a proxy for asset distribution. Different definitions of the inequality variable may account for the different results also obtained by DeININGER and Squire (1998) and Bagchi and Svejnar (2015). In both papers, in fact, it is claimed that wealth inequality has a negative impact on GDP growth.

Our estimation results are not robust to alternative model specifications, such as the inclusion or the exclusion of continent or year dummies. From equation (8) in Table 6, indeed, we get some indication that being in the Asia or in Africa is a factor that hinders real per capita GDP growth of a country. However, in 
equation (8) the estimated coefficient of wealth inequality is no longer statistically significant. This is consistent with the results obtained by DeIninger and SQuire (1999). The authors find, in fact, that the link between income inequality and growth is tenuous and that it disappears once geographic dummies are included in the model.

As for the other explanatory variables in Table 6, the PPP term is never statistically significant; the same holds for the interaction terms between wealth Gini and the controls. The coefficient of initial income is negative in most estimates. This finding is broadly consistent with Kostov and Le Gallo (2015); however, this coefficient is never statistically significant. The impact of education on growth, when statistically significant, is always negative. These results are consistent with FORBES (2000). The author, in fact, finds evidence of a negative coefficient for male education.

The sign of the estimated coefficient for the education variable may be explained with the arguments of Barro (2000) and Grijalva (2011). Both authors claim, in fact, that it is possible that education causes an increase in the growth rate only after a minimum threshold has been reached. Below this threshold, additional education could have a negative impact on short-term growth, because the resources used for education could have been used for productive activities generating immediate returns. Moreover, it is known that the investment in human capital represents a cost in the short term and yields a positive return only in the long term.

The Hansen test confirms the overall validity of the instruments used for the endogenous variables in all model specifications. This means that the estimates should be unbiased. From first-stage results of the GMM estimation, which are reported in Appendix B, we deduce that our GMM estimation strategy is valid. For each estimate and for all the endogenous variables, in fact, we can reject the null hypothesis that the endogenous regressor is weakly identified at a confidence level of $95 \%$ and, in most cases, of $99 \%$.

The results of the Cumby-Huizinga test for serial correlation in the residuals are also reported in Table 6 . We find evidence that the residuals are not serially correlated. At a $95 \%$ confidence level, in fact, we never reject the null hypothesis of absence of first-order serial correlation of the error terms; the same holds for second-order serial correlation. Hence, we find no evidence of model misspecification (BAUM and SCHAFFER, 2015). 


\subsection{Robustness Checks}

In order to check the robustness of our results, we run some additional estimates. The main results are reported in Table 7.

In particular, we adopt three estimation strategies. First, we consider an extended sample, which includes 154 countries for the period 1990-2014; due to limitations in data availability for the wealth Gini coefficient, in this extended sample we consider the income Gini coefficient as the inequality variable.

Second, we exclude from our main sample (146 countries, period 20102014) those data on wealth Gini that are classified as of "very poor quality" or "unknown quality" in the Credit Suisse Reports. In this way, we obtain a highquality sample of 114 countries for the period 2010-2014. Third, we divide our main sample (146 countries, 2010-2014) into two subsamples, one including the rich countries and the other including the poor ones. Following BARRO (2008), the division has been performed using the median initial per capita income of the whole sample as a threshold.

\subsubsection{Evidence from the Extended Sample (154 Countries, 1990-2014)}

With reference to the extended sample, in which the income Gini is used as the inequality measure and the time horizon is longer, the estimated coefficient is never statistically significant in any alternative model specification. The squared Gini term, too, turns out to be statistically insignificant in all the estimations. In addition, the other variables are rarely statistically significant. We only get some indication of a negative impact of the Asia dummy on the annual growth rate of real per capita GDP.

\subsubsection{Estimation Results from the High-Quality Sample (114 Countries, 2010-2014)}

On the other hand, estimation of our growth regression on the high-quality subsample again gives us evidence of a positive relationship between wealth inequality and real per capita GDP growth. It is worth noting, however, that if we exclude the interaction terms from equation (12), the estimated coefficient of the wealth Gini is no longer statistically significant (results not reported).

From equation (12) in Table 7 we also get some indication of the existence of a negative relationship between the PPP variable and the annual rate of per capita GDP growth. This result is in line with the previous literature, even though the size of the estimated coefficient here is larger. The variable PPP is the price level ratio of the PPP conversion factor to market exchange rate, as recorded 
Table 7: Robustness Check Estimates

\begin{tabular}{|c|c|c|c|c|c|c|c|c|}
\hline \multirow{2}{*}{$\begin{array}{l}\text { Variable } \\
\text { Initial income }\end{array}$} & \multicolumn{2}{|c|}{$\begin{array}{c}\text { (11) Arellano-Bond } \\
\text { GMM two-step, } \\
\text { income Gini, with continent } \\
\text { dummies, squared Gini } \\
\text { term and interaction terms, } \\
154 \text { countries }\end{array}$} & \multicolumn{2}{|c|}{$\begin{array}{c}\text { (12) Arellano-Bond } \\
\text { GMM two-step, } \\
\text { only high quality data on } \\
\text { wealth Gini, with interaction } \\
\text { terms, } 114 \text { countries }\end{array}$} & \multicolumn{2}{|c|}{$\begin{array}{l}\text { (13) Arellano-Bond } \\
\text { GMM two-step, } \\
\text { wealth Gini, only rich } \\
\text { countries, } 73 \text { countries }\end{array}$} & \multicolumn{2}{|c|}{$\begin{array}{c}\text { (14) Arellano-Bond } \\
\text { GMM two-step, } \\
\text { wealth Gini, only poor } \\
\text { countries, with interaction } \\
\text { terms, } 73 \text { countries }\end{array}$} \\
\hline & -216.06 & $(151.57)$ & -2.38 & $(4.43)$ & -0.07 & $(0.44)$ & 0.19 & $(6.31)$ \\
\hline Income Gini & 14.97 & $(9.40)$ & \multicolumn{2}{|c|}{-} & \multicolumn{2}{|c|}{-} & \multicolumn{2}{|c|}{-} \\
\hline Wealth Gini & \multicolumn{2}{|c|}{-} & $0.19^{* *}$ & $(0.09)$ & $0.06^{*}$ & $(0.04)$ & 0.11 & $(0.09)$ \\
\hline Edu & 11.33 & $(7.66)$ & 0.46 & $(0.36)$ & -0.02 & $(0.03)$ & 0.31 & $(0.37)$ \\
\hline PPP & 857.10 & $(794.97)$ & $-35.74^{*}$ & (19.93) & -0.06 & $(1.57)$ & -48.15 & $(39.45)$ \\
\hline Squared Gini & -0.21 & $(0.17)$ & \multicolumn{2}{|c|}{-} & \multicolumn{2}{|c|}{-} & \multicolumn{2}{|c|}{-} \\
\hline Init. income $*$ Gini & 4.27 & $(3.21)$ & 0.02 & $(0.06)$ & \multicolumn{2}{|c|}{-} & -0.01 & $(0.10)$ \\
\hline Edu $*$ Gini & -0.25 & $(0.17)$ & -0.01 & $(0.01)$ & \multicolumn{2}{|c|}{-} & -0.004 & $(0.01)$ \\
\hline $\mathrm{PPP} *$ Gini & -19.19 & $(17.55)$ & $0.50^{*}$ & $(0.28)$ & \multicolumn{2}{|c|}{-} & 0.63 & $(0.58)$ \\
\hline Asia & $-69.47^{*}$ & $(36.68)$ & \multicolumn{2}{|c|}{-} & \multicolumn{2}{|c|}{-} & \multicolumn{2}{|c|}{-} \\
\hline Africa & -71.82 & $(58.19)$ & \multicolumn{2}{|c|}{-} & \multicolumn{2}{|c|}{-} & \multicolumn{2}{|c|}{-} \\
\hline America & -58.14 & $(37.36)$ & \multicolumn{2}{|c|}{-} & \multicolumn{2}{|c|}{-} & \multicolumn{2}{|c|}{-} \\
\hline $\begin{array}{l}\text { P-value Cumby- } \\
\text { Huizinga test (lag 1) }\end{array}$ & \multicolumn{2}{|l|}{0.63} & \multicolumn{2}{|l|}{1.00} & \multicolumn{2}{|l|}{1.00} & \multicolumn{2}{|l|}{1.00} \\
\hline
\end{tabular}




\begin{tabular}{|c|c|c|c|c|}
\hline Variable & $\begin{array}{c}\text { (11) Arellano-Bond } \\
\text { GMM two-step, } \\
\text { income Gini, with continent } \\
\text { dummies, squared Gini } \\
\text { term and interaction terms, } \\
154 \text { countries }\end{array}$ & $\begin{array}{l}\text { (12) Arellano-Bond } \\
\text { GMM two-step, } \\
\text { only high quality data on } \\
\text { wealth Gini, with interaction } \\
\text { terms, } 114 \text { countries }\end{array}$ & $\begin{array}{l}\text { (13) Arellano-Bond } \\
\text { GMM two-step, } \\
\text { wealth Gini, only rich } \\
\text { countries, } 73 \text { countries }\end{array}$ & $\begin{array}{c}\text { (14) Arellano-Bond } \\
\text { GMM two-step, } \\
\text { wealth Gini, only poor } \\
\text { countries, with interaction } \\
\text { terms, } 73 \text { countries }\end{array}$ \\
\hline $\begin{array}{l}\text { P-value Cumby- } \\
\text { Huizinga test (lag 2) }\end{array}$ & 0.85 & 1.00 & 1.00 & 1.00 \\
\hline P-value Hansen Test & 0.59 & 0.45 & 0.70 & 0.18 \\
\hline N. of obs. & $2 ' 543$ & 323 & $193^{a}$ & 182 \\
\hline Variable & $\begin{array}{l}\text { (15) Arellano-Bond } \\
\text { GMM two-step, } \\
\text { wealth Gini, only rich } \\
\text { countries, with interaction } \\
\text { terms, } 73 \text { countries }\end{array}$ & $\begin{array}{l}\text { (16) Arellano-Bond } \\
\text { GMM two-step, } \\
\text { wealth Gini, only poor } \\
\text { countries, } 73 \text { countries }\end{array}$ & $\begin{array}{c}\text { (17) Arellano-Bond } \\
\text { GMM two-step, } \\
\text { wealth Gini, only rich } \\
\text { countries, with Gini squared } \\
\text { and interaction terms, } \\
73 \text { countries }\end{array}$ & $\begin{array}{c}\text { (18) Arellano-Bond } \\
\text { GMM two-step, } \\
\text { wealth Gini, only poor } \\
\text { countries, with Gini squared } \\
\text { and interaction terms, } \\
73 \text { countries }\end{array}$ \\
\hline Initial income & $(2.42)$ & $(1.00)$ & -3.36 & $(8.44)$ \\
\hline Income Gini & - & - & - & - \\
\hline Wealth Gini & $0.12^{* *} \quad(0.06)$ & $(0.08)$ & $(0.45)$ & $(0.94)$ \\
\hline Edu & $0.47^{* *} \quad(0.23)$ & $(0.02)$ & $(0.34)$ & $(0.83)$ \\
\hline PPP & $-12.91 \quad(12.36)$ & $-6.91^{* * *} \quad(2.02)$ & $-14.36 \quad(13.56)$ & $-99.84 \quad(62.24)$ \\
\hline Squared Gini & - & - & $0.0004 \quad(0.01)$ & $(0.01)$ \\
\hline Init. income $*$ Gini & $0.04 \quad(0.03)$ & - & $(0.04)$ & $(0.13)$ \\
\hline
\end{tabular}




\begin{tabular}{|c|c|c|c|c|c|c|}
\hline \multirow{2}{*}{$\begin{array}{l}\text { Variable } \\
\\
\text { Edu } * \text { Gini }\end{array}$} & $\begin{array}{l}\text { (15) Arellano-Bond } \\
\text { GMM two-step, } \\
\text { wealth Gini, only rich } \\
\text { countries, with interaction } \\
\text { terms, } 73 \text { countries }\end{array}$ & \multirow{2}{*}{$\begin{array}{l}\text { (16) Arellano-Bond } \\
\text { GMM two-step, } \\
\text { wealth Gini, only poor } \\
\text { countries, } 73 \text { countries } \\
-\end{array}$} & \multicolumn{2}{|c|}{$\begin{array}{l}\text { (17) Arellano-Bond } \\
\text { GMM two-step, } \\
\text { wealth Gini, only rich } \\
\text { countries, with Gini squared } \\
\text { and interaction terms, } \\
73 \text { countries }\end{array}$} & \multicolumn{2}{|c|}{$\begin{array}{c}\text { (18) Arellano-Bond } \\
\text { GMM two-step, } \\
\text { wealth Gini, only poor } \\
\text { countries, with Gini squared } \\
\text { and interaction terms, } \\
73 \text { countries }\end{array}$} \\
\hline & $-0.01^{* *} \quad(0.003)$ & & -0.01 & $(0.004)$ & -0.01 & $(0.01)$ \\
\hline $\mathrm{PPP} *$ Gini & $0.16 \quad(0.17)$ & - & 0.19 & $(0.19)$ & 1.42 & $(0.94)$ \\
\hline Asia & - & - & & & & \\
\hline Africa & - & - & & & & \\
\hline America & - & - & & & & \\
\hline $\begin{array}{l}\text { P-value Cumby- } \\
\text { Huizinga test (lag 1) }\end{array}$ & 1.00 & 1.00 & 1.00 & & 1.00 & \\
\hline $\begin{array}{l}\text { P-value Cumby- } \\
\text { Huizinga test (lag 2) }\end{array}$ & 1.00 & 1.00 & 1.00 & & 1.00 & \\
\hline P-value Hansen Test & 0.56 & 0.07 & 0.45 & & 0.36 & \\
\hline N. of obs. & 193 & 182 & 193 & & 182 & \\
\hline
\end{tabular}

Notes: The dependent variable is the annual growth rate of real per capita GDP in all model specifications. Standard errors are robust to heteroskedasticity and clustered on countries. In all model specification the following variables are considered endogenous and thus instrumented: initial income, wealth Gini (substituted by income Gini in equation (11), education and, when present in the estimating equation, also the squared Gini term and the three interaction terms between Gini and the other explanatory variables (Initial Income* Gini, Education*Gini and PPP*Gini). Source: Author's own elaboration.

a The number of observations in the subsample of rich countries differs from the number of observations in the subsample of poor countries due to a different number of missing data. However, both subsamples include 73 countries. 
by the World Bank. The purchasing power parity conversion factor, in turn, is the number of units of a country's currency which are required to buy the same amount of goods and services in the domestic market as a USD would buy in the USA. This variable is then divided by the market exchange rate.

This ratio is also called the national price level and makes cost comparisons possible between countries. A high domestic price level is often associated with a high level of market distortions. In the past literature, in fact, the variable PPP (or slight different definitions of it) is always negatively associated with economic growth. Grijalva (2011), for example, finds evidence of a negative impact of the high price of investment (a variable that he uses to measure the degree of market distortions) on GDP growth.

With reference to equation (12) in Table 7 , the sign of the interaction term between the wealth Gini and the PPP variable is positive and statistically significant at a confidence level of $90 \%$. This seems to imply that the positive impact of wealth inequality on the growth rate of real per capita GDP is higher in the presence of a high value of the PPP variable.

\subsubsection{Evidence from the Two Subsamples of Rich and Poor Countries (73 Countries Each, 2010-2014)}

As an additional robustness check, we divide the restricted sample into two subsamples (equations from (13) to (18) in Table 7), one including rich countries and the other with the poorer ones. In the subsample of poor countries, the estimated coefficient of the wealth Gini is never statistically significant. The estimated coefficients of the other variables, too, are rarely significant. Again, we only get some evidence of a negative impact of the PPP variable on the annual growth rate of real per capita GDP.

On the contrary, in the subsample of rich countries, we get some evidence that there exists a positive relationship between wealth inequality and the growth rate of real GDP per capita. There is also a hint (equation 15) at the existence of a positive impact of education on GDP per capita growth, which is consistent with the considerations on the education variable presented in Section 4.2. Moreover, in equation (15) the sign of the interaction term between education and the wealth Gini coefficient is negative. This suggests that, in rich countries, the lower the average education level is, the higher the positive impact of wealth inequality on GDP per capita growth will be. However, none of these results is robust to the inclusion of the Gini squared term in the estimating equation. Since the squared Gini term is never statistically significant in any of the two subsamples, in this case we did not try to compute the optimal inequality level on the basis of the estimation results. 
The fact that we obtained different results in the subsample of rich countries and in that of poor ones is consistent with the previous literature. BARRO (2008) and Pagano (2004), for example, suggest that income inequality may have a positive impact on GDP growth in rich countries but a negative impact on GDP growth in poor countries. However, we do not find evidence of the existence of a negative relationship between wealth inequality and real per capita GDP growth in any model specification for the subsample of poor countries. Moreover, the estimated coefficient of the interaction term between the wealth Gini coefficient and initial real per capita income is never statistically significant in either of the two subsamples.

For all the estimates presented in Table 7, the Hansen test confirms the validity of the instruments employed and the F-statistics of excluded instruments, reported in Appendix B, confirms again that the endogenous regressors are identified. Moreover, at a $95 \%$ confidence level we never reject the hypothesis of absence of first-order serial correlation of the residuals; the same holds for second-order serial correlation (see results of the Cumby-Huizinga test reported in Table 7).

\section{Concluding Remarks}

The relationship between wealth inequality and real GDP per capita growth seems not to be robust to different model specifications. Even though we get some evidence of a positive relationship between the wealth Gini coefficient and the annual growth rate of real per capita GDP from our Arellano-Bond GMM estimates, the statistical significance of this relationship is not stable across different model specifications.

The same holds when income Gini instead of wealth Gini is considered as the inequality measure. Different estimation methods yield different results and the difference between these results is not negligible. The size of the estimated coefficient of the inequality variable, in fact, varies considerably across the alternative model specifications.

In our main sample (146 countries), for example, the inclusion of continent dummies in the estimating equation causes the estimated coefficient of the wealth Gini to lose its statistical significance. As mentioned before, the results obtained seem to be highly dependent on model formulation. It is likely that the relationship between inequality and real per capita GDP growth is not robust and that there exists a variable that contributes to the determination of both economic growth and inequality simultaneously. The identification of this variable constitutes scope for future research. 


\section{Appendix A. Inequality Data $2010-2014^{7}$}

\begin{tabular}{lccccc|ccccc}
\hline & \multicolumn{4}{c|}{ Wealth Gini coefficient } & \multicolumn{5}{c}{ Income Gini coefficient } \\
Country & 2010 & 2011 & 2012 & 2013 & 2014 & 2010 & 2011 & 2012 & 2013 & 2014 \\
\hline Algeria & 68.2 & 66.2 & 65.6 & 65.5 & 67.6 & - & - & - & - & - \\
\hline Australia & 72.7 & 62.6 & 63.6 & 63.6 & 64 & 46.5 & 47.3 & 48.1 & 48.1 & 48.1 \\
\hline Austria & 64.6 & 69 & 69.3 & 77.8 & 77.9 & 46.2 & 46.3 & 46.7 & 45.3 & 45.3 \\
\hline Azerbaijan & 61.2 & 59.5 & 65.2 & 65.1 & 64.6 & 31.8 & 31.8 & 31.8 & - & - \\
\hline Bahamas, The & 64.7 & 67 & 66.4 & 66.2 & 72.3 & - & - & - & - & - \\
\hline Bahrain & 60.2 & 58.1 & 59.1 & 58.5 & 66.1 & - & - & - & - & - \\
\hline Bangladesh & 65.6 & 65 & 64.7 & 64.6 & 67.8 & 46.3 & 46.3 & 46.3 & 46.3 & 46.3 \\
\hline Barbados & 66.3 & 69.7 & 69.1 & 69 & 75.7 & 53.8 & 53.8 & 53.8 & 53.8 & 53.8 \\
\hline Belarus & 64.8 & 63.7 & 62.4 & 62.2 & 64.6 & 28.4 & 26.9 & 28.1 & 28.1 & 28.1 \\
\hline Belgium & 67 & 66.3 & 65.5 & 62.6 & 62.9 & 43.1 & 47.4 & 45.6 & 45.6 & 45.6 \\
Belize & 73.6 & 96.6 & 96.2 & 73.1 & 77.3 & - & - & - & - & - \\
\hline Benin & 67.8 & 67.2 & 67.1 & 66.5 & 67.8 & - & 39.8 & - & - & - \\
Bolivia & 77.3 & 75.6 & 74.5 & 74.4 & 74.5 & 47.2 & 46.0 & 45.3 & 45.3 & 45.3 \\
\hline Brunei Darussalam & 58.4 & 58.1 & 59.1 & 58.5 & 66.3 & - & - & - & - & - \\
\hline Bulgaria & 65.5 & 63.9 & 62.6 & 62.5 & 66.6 & 31.6 & 40.2 & 37.5 & 38.6 & 38.6 \\
\hline Burkina Faso & 69.4 & 68.3 & 67.8 & 67.7 & 66.8 & 37.2 & 37.2 & 37.2 & 37.2 & - \\
\hline Burundi & 67 & 66 & 65.3 & 65.2 & 63.8 & 37.5 & - & - & - & - \\
\hline Cabo Verde & 74.4 & 72.9 & 100 & 72.3 & 78.9 & - & - & - & - & - \\
\hline Cameroon & 70.3 & 67.3 & 67.2 & 67.7 & 70.3 & 39.7 & 39.7 & - & - & - \\
\hline Canada & 68.3 & 72.3 & 72.4 & 72.7 & 72.6 & 47.5 & 47.4 & 47.4 & 47.4 & 47.4 \\
\hline Central African Republic & 72 & 69.7 & 74.9 & 74.8 & 71.3 & - & - & - & - & - \\
\hline Chad & 70.2 & 68.2 & 67.6 & 67.5 & 66.5 & - & - & - & - & - \\
Chile & 64.7 & 78.2 & 77.4 & 81.4 & 78.9 & 51.5 & 52.1 & 52.1 & 52.1 & 52.1 \\
\hline
\end{tabular}

7 The sources of the data on the wealth Gini coefficient are the following: Davies, Lluberas and Shorrocks (2010), Davies, Lluberas and Shorrocks (2011), Davies, Lluberas and Shorrocks (2012), Davies, Lluberas and Shorrocks (2013), Davies, Lluberas and ShorROCKs (2014). Data on the income Gini coefficient have been taken from Solt (2014). For brevity, in this Appendix data relative to the income Gini coefficient are reported only for those countries and years for which information on wealth Gini is also available. If a value of the Gini is missing, it is replaced with the nearest value for the same country in the previous five years; these replaced values are reported in italics in Appendix A. 


\begin{tabular}{|c|c|c|c|c|c|c|c|c|c|c|}
\hline \multirow[b]{2}{*}{ Country } & \multicolumn{5}{|c|}{ Wealth Gini coefficient } & \multicolumn{5}{|c|}{ Income Gini coefficient } \\
\hline & 2010 & 2011 & 2012 & 2013 & 2014 & 2010 & 2011 & 2012 & 2013 & 2014 \\
\hline China & 69 & 69.7 & 68.9 & 69.5 & 71.9 & 49.3 & 49.1 & 52.4 & 56.9 & 56.9 \\
\hline Colombia & 79.5 & 79.2 & 78.8 & 79.7 & 76.8 & 50.4 & 49.4 & 49.5 & 49.5 & 49.5 \\
\hline Comoros & 78.2 & 79.1 & 78.7 & 78.7 & 80.8 & - & - & - & - & - \\
\hline Congo, Dem. Rep. & 70.9 & 70.2 & 69.6 & 69.6 & 68.6 & 46.4 & - & - & - & - \\
\hline Congo, Rep. & 74.3 & 71.4 & 71 & 70.8 & 71.7 & - & - & - & - & - \\
\hline Costa Rica & 76.7 & 72.1 & 72.3 & 72.2 & 76.7 & 48.3 & 47.0 & 50.4 & 48.1 & 48.1 \\
\hline Cote d'Ivoire & 73.4 & 72 & 68.2 & 68.1 & 72.1 & - & - & - & - & - \\
\hline Croatia & 65.1 & 63.8 & 65.2 & 65.1 & 66.1 & 39.8 & 39.8 & 39.8 & - & - \\
\hline Cyprus & 61.3 & 75 & 75.3 & 78.3 & 80.5 & 48.2 & 49.4 & 51.8 & 49.2 & 49.2 \\
\hline Czech Republic & 62.5 & 74.7 & 74.3 & 74 & 77.4 & 45.1 & 42.2 & 44.5 & 40.5 & 40.5 \\
\hline Denmark & 84 & - & 70.1 & - & 89.1 & 46.3 & 47.8 & 48.3 & 48.7 & 48.7 \\
\hline Djibouti & 66.5 & 68.2 & 67.6 & 67.5 & 67.4 & - & - & - & - & - \\
\hline Dominica & 61.5 & 73 & 72.1 & 72 & 75.5 & 47.0 & 46.8 & 46.8 & 46.8 & 46.8 \\
\hline Ecuador & 76.8 & 74.4 & 71.5 & 71.4 & 75.2 & 47.2 & 47.3 & 46.7 & 46.7 & 46.7 \\
\hline Egypt, Arab Rep. & 67.8 & 80.1 & 80.4 & 80.3 & 80.7 & 33.3 & 33.3 & 33.3 & 33.3 & - \\
\hline El Salvador & 73.3 & 71 & 71.1 & 71 & 72.6 & 43.5 & 43.0 & 42.0 & 42.0 & 42.0 \\
\hline Estonia & 71.9 & 66.5 & 66 & 65.7 & 68.2 & 48.6 & 51.0 & 49.8 & 52.9 & 52.9 \\
\hline Fiji & 72.8 & 70.1 & 69.1 & 69 & 68.8 & 40.0 & 40.0 & 40.0 & 40.0 & - \\
\hline Finland & 57.8 & 66.3 & 66.2 & 66.4 & 71.5 & 47.9 & 48.1 & 46.2 & 47.2 & 47.2 \\
\hline France & 75.8 & 75.4 & 75.5 & 69 & 69.7 & 46.8 & 51.0 & 48.4 & 48.4 & 46.8 \\
\hline Gambia, The & 71.9 & 71.4 & 70.8 & 70.8 & 70 & 50.2 & 50.2 & - & - & - \\
\hline Georgia & 70.3 & 68.4 & 79 & 68 & 68 & 46.2 & 45.8 & 43.1 & 44.2 & 44.2 \\
\hline Germany & 68.4 & 75 & 77.7 & 77.1 & 77.1 & 51.6 & 50.9 & 48.8 & 48.8 & 48.8 \\
\hline Ghana & 70.3 & 69.3 & 68.7 & 68.6 & 66.8 & - & - & - & - & - \\
\hline Greece & 66.4 & 70.3 & 71.4 & 65.9 & 68.1 & 50.7 & 51.6 & 52.7 & 52.7 & 52.7 \\
\hline Grenada & 66 & 72.9 & 72 & 71.9 & 73.1 & - & - & - & - & - \\
\hline Guinea & 70.6 & 69.8 & 67.4 & 67.3 & 66.3 & - & 40.4 & - & - & - \\
\hline Guyana & 68.2 & 69.9 & 69.3 & 69.2 & 72.4 & 36.9 & - & - & - & - \\
\hline Hong Kong SAR, China & 85.6 & 83.9 & 83.6 & 83.1 & 84.2 & 52.9 & 52.9 & 52.9 & 52.9 & 52.9 \\
\hline Hungary & 65.3 & 64.2 & 64.1 & 64 & 64.7 & 48.3 & 47.8 & 48.9 & 50.3 & 50.3 \\
\hline Iceland & 62.9 & 66.6 & 66.3 & 67.3 & 68.4 & 38.3 & 38.6 & 36.1 & 34.8 & 34.8 \\
\hline India & 77.8 & 80.4 & 81.3 & 81.3 & 81.4 & 51.6 & 51.6 & 51.6 & 51.6 & 51.6 \\
\hline
\end{tabular}




\begin{tabular}{|c|c|c|c|c|c|c|c|c|c|c|}
\hline \multirow[b]{2}{*}{ Country } & \multicolumn{5}{|c|}{ Wealth Gini coefficient } & \multicolumn{5}{|c|}{ Income Gini coefficient } \\
\hline & 2010 & 2011 & 2012 & 2013 & 2014 & 2010 & 2011 & 2012 & 2013 & 2014 \\
\hline Indonesia & 77.3 & 81.2 & 82 & 82.8 & 84 & 44.2 & 41.6 & 47.0 & 46.1 & 46.1 \\
\hline Iran, Islamic Rep. & 68.2 & 67.5 & 66.9 & 66.8 & 67.4 & 39.5 & 38.9 & 38.9 & 38.9 & 38.9 \\
\hline Ireland & 58.9 & 71.6 & 72.7 & 70.9 & 71.6 & 56.2 & 54.6 & 52.0 & 52.0 & 52.0 \\
\hline Israel & 77.5 & 77.3 & 78.3 & 78.7 & 77.3 & 51.3 & 49.6 & 49.6 & 49.6 & 49.6 \\
\hline Italy & 62.6 & 61.3 & 64.6 & 65 & 66.1 & 49.7 & 49.4 & 48.5 & 50.9 & 50.9 \\
\hline Jamaica & 74.9 & 70.6 & 70 & 69.9 & 76.8 & - & - & - & - & - \\
\hline Japan & 60.7 & 60.1 & 59.6 & 63.5 & 63.4 & 46.7 & 46.7 & 46.7 & 46.7 & 46.7 \\
\hline Jordan & 69.3 & 67.5 & 65.9 & 65.9 & 66.1 & 37.3 & 37.3 & 37.3 & 37.3 & 37.3 \\
\hline Kazakhstan & 65.8 & 86.3 & 83.8 & 86.7 & 87.3 & 31.6 & 31.6 & 30.5 & 33.1 & 33.1 \\
\hline Kenya & 72.4 & 71.5 & 71 & 70.9 & 70.7 & 49.9 & 49.9 & - & - & - \\
\hline Korea, Rep. & 60.7 & 68 & 72.6 & 72.6 & 74.1 & 34.1 & 33.8 & 34.3 & 33.1 & 33.1 \\
\hline Kyrgyz Republic & 67.3 & 65.9 & 66 & 65.9 & 64.6 & 36.3 & 35.8 & 35.8 & 35.8 & 35.8 \\
\hline Lao PDR & 67 & 65.4 & 66.6 & 66.5 & 64.3 & 39.0 & 39.0 & 39.0 & - & - \\
\hline Latvia & 69.2 & 66.6 & 66.1 & 66 & 67.9 & 53.5 & 53.3 & 58.3 & 58.7 & 58.7 \\
\hline Lebanon & 79.7 & 85.8 & 85.7 & 86.3 & 85.8 & - & - & - & - & - \\
\hline Lesotho & 78.7 & 73.4 & 72.8 & 72.9 & 73.7 & - & - & - & - & - \\
\hline Liberia & 69.8 & 67.5 & 66.8 & 66.7 & 65.9 & - & 51.1 & 51.1 & 51.1 & 51.1 \\
\hline Lithuania & 68.5 & 66.4 & 66.6 & 66.5 & 67.1 & 55.3 & 54.5 & 51.7 & 53.8 & 53.8 \\
\hline Luxembourg & 62.6 & 62.9 & 62.3 & 65.7 & 70.2 & 46.1 & 45.8 & 46.4 & 46.4 & 46.4 \\
\hline Macedonia, FYR & 72.7 & 69.4 & 68.9 & 68.8 & 69 & 42.6 & 42.6 & 42.6 & 42.6 & 42.6 \\
\hline Madagascar & 72.4 & 71.7 & 69.4 & 69.4 & 68.5 & 50.3 & 50.3 & 50.3 & 50.3 & 50.3 \\
\hline Malawi & 69.2 & 68 & 67.4 & 67.3 & 67.2 & 45.9 & 51.1 & 51.1 & 51.1 & 51.1 \\
\hline Malaysia & 69.4 & 80.4 & 81.4 & 81.5 & 80.8 & 44.4 & 43.6 & 42.9 & 42.9 & 42.9 \\
\hline Mali & 69.2 & 67.9 & 64.8 & 64.7 & 66.3 & 36.5 & 36.5 & 36.5 & 36.5 & 36.5 \\
\hline Malta & 65.8 & 66.7 & 66.4 & 59.5 & 60.7 & 47.8 & 46.8 & 45.4 & 42.3 & 42.3 \\
\hline Mauritania & 70.7 & 67.8 & 67.8 & 67.7 & 67.1 & 41.6 & 41.6 & 41.6 & - & - \\
\hline Mauritius & 68.3 & 65.3 & 64.6 & 64.5 & 74.1 & 40.6 & - & - & - & - \\
\hline Mexico & 78 & 77.4 & 78 & 78 & 75.9 & 46.6 & 47.0 & 47.5 & 47.5 & 47.5 \\
\hline Moldova & 68.8 & 67.1 & 64.8 & 64.7 & 68 & 34.9 & 35.8 & 33.4 & 33.4 & 33.4 \\
\hline Mongolia & 69.4 & 66.9 & 66.2 & 66.1 & 64.3 & 34.5 & 34.5 & 34.5 & 34.5 & 34.5 \\
\hline Montenegro & 65.2 & 66.9 & 63.5 & 63.4 & 65.7 & 34.0 & 34.0 & 34.0 & 34.0 & 34.0 \\
\hline Morocco & 71.5 & 68.8 & 79.6 & 68.1 & 79 & 44.2 & 44.2 & - & - & - \\
\hline
\end{tabular}




\begin{tabular}{|c|c|c|c|c|c|c|c|c|c|c|}
\hline \multirow[b]{2}{*}{ Country } & \multicolumn{5}{|c|}{ Wealth Gini coefficient } & \multicolumn{5}{|c|}{ Income Gini coefficient } \\
\hline & 2010 & 2011 & 2012 & 2013 & 2014 & 2010 & 2011 & 2012 & 2013 & 2014 \\
\hline Mozambique & 72.6 & 71.5 & 70.2 & 70 & 70.2 & 49.1 & 49.1 & 49.1 & - & - \\
\hline Nepal & 72.7 & 71.9 & 64.8 & 64.7 & 68.6 & 39.9 & 39.9 & 39.9 & 39.9 & 39.9 \\
\hline Netherlands & 64.3 & 81.2 & 81.2 & 73.2 & 72.6 & 45.7 & 46.2 & 47.1 & 47.1 & 47.1 \\
\hline New Zealand & 75.4 & 72.2 & 72.5 & 71.8 & 71 & 46.9 & 50.6 & 48.8 & 46.0 & 46.0 \\
\hline Nicaragua & 75.2 & 73.5 & 73 & 73 & 71.4 & 45.0 & 45.0 & 45.0 & 45.0 & - \\
\hline Niger & 71.4 & 70 & 65.7 & 65.5 & 66.4 & 35.8 & 35.8 & 35.8 & - & - \\
\hline Nigeria & - & - & - & 80 & 80.3 & 45.1 & 43.7 & 43.7 & 43.7 & 43.7 \\
\hline Norway & 66.2 & 77.7 & 77.9 & 77.8 & 77.8 & 44.6 & 45.6 & 42.2 & 42.2 & 42.2 \\
\hline Oman & 74.3 & 68.4 & 70.8 & 70.8 & 76.9 & - & - & - & - & - \\
\hline Pakistan & 65.6 & 65 & 63.9 & 63.8 & 62.5 & 40.7 & 42.5 & 42.5 & 42.5 & 42.5 \\
\hline Panama & 79.5 & 74.3 & 72.7 & 72.7 & 78.3 & 51.0 & 48.5 & 49.9 & 49.9 & 49.9 \\
\hline Papua New Guinea & 74.3 & 73 & 72.5 & 72.4 & 72.2 & - & - & - & - & - \\
\hline Paraguay & 75.6 & 73.8 & 72.8 & 72.8 & 75.6 & 50.6 & 51.0 & 51.0 & 51.0 & 51.0 \\
\hline Peru & 75.2 & 72.5 & 77.4 & 70.8 & 81.7 & 47.2 & 47.5 & 47.5 & 47.5 & 47.5 \\
\hline Philippines & 70.8 & 73 & 81 & 82.9 & 83.5 & - & - & - & 47.8 & 47.8 \\
\hline Poland & 66.8 & 74.9 & 75.3 & 73.7 & 74.9 & 47.4 & 47.5 & 46.2 & 47.1 & 47.1 \\
\hline Portugal & 68.7 & 72.3 & 72.5 & 70.1 & 70.4 & 51.1 & 54.4 & 55.7 & 55.7 & 55.7 \\
\hline Qatar & 85.6 & 71.1 & 70.6 & 70.5 & 72.9 & - & - & - & - & - \\
\hline Romania & 65.9 & 76 & 73.1 & 73 & 73.6 & 41.0 & 41.3 & 41.8 & 41.8 & 41.8 \\
\hline Russian Federation & 70.6 & 91.6 & 91.4 & 93.1 & 89.7 & 52.2 & 49.9 & 49.9 & 49.9 & 49.9 \\
\hline Rwanda & 72 & 71.3 & 72.7 & 72.7 & 72.2 & 54.1 & 50.1 & 50.1 & 50.1 & 50.1 \\
\hline Samoa & - & - & - & 67 & 69.9 & - & - & - & - & - \\
\hline Sao Tome and Principe & - & - & - & 72.7 & 73.2 & - & - & - & - & - \\
\hline Saudi Arabia & 71 & 79.2 & 79.2 & 79.3 & 77.3 & - & - & - & - & - \\
\hline Senegal & 69.5 & 67.9 & 67.3 & 67.2 & 67.3 & 40.9 & 41.2 & 41.2 & 41.2 & 41.2 \\
\hline Serbia & 64.5 & 63.5 & 62.6 & 62.5 & 65.4 & 31.3 & 31.3 & 31.3 & 31.3 & 31.3 \\
\hline Seychelles & 68.8 & 80.2 & 79.7 & 79.6 & 88.1 & 45.5 & 45.5 & - & - & - \\
\hline Sierra Leone & 71.1 & 69.4 & 68.9 & 68.8 & 66.2 & - & 35.6 & 35.6 & 35.6 & 35.6 \\
\hline Slovak Republic & 69.5 & 62.6 & 62.1 & 44.7 & 44.7 & 42.5 & 41.7 & 42.2 & 42.9 & 42.9 \\
\hline Slovenia & 68.1 & 64.6 & 63.9 & 53.5 & 53.8 & 41.5 & 40.8 & 39.7 & 40.5 & 40.5 \\
\hline Solomon Islands & 69.4 & 69.2 & 68.3 & 68.1 & 65.8 & - & - & - & - & - \\
\hline South Africa & 81.6 & 79.4 & 82.6 & 83.6 & 81.8 & 69.3 & 66.8 & 66.8 & 66.8 & 66.8 \\
\hline
\end{tabular}




\begin{tabular}{|c|c|c|c|c|c|c|c|c|c|c|}
\hline \multirow[b]{2}{*}{ Country } & \multicolumn{5}{|c|}{ Wealth Gini coefficient } & \multicolumn{5}{|c|}{ Income Gini coefficient } \\
\hline & 2010 & 2011 & 2012 & 2013 & 2014 & 2010 & 2011 & 2012 & 2013 & 2014 \\
\hline Spain & 56.5 & 63.4 & 66.2 & 66.1 & 67.1 & 51.2 & 50.3 & 51.0 & 49.5 & 49.5 \\
\hline Sri Lanka & 69.5 & 68.8 & 68.1 & 68 & 66.9 & 42.6 & 44.2 & 45.9 & 44.3 & 44.3 \\
\hline St. Kitts and Nevis & - & - & 99.7 & 71.9 & 75.4 & - & - & - & - & - \\
\hline St. Lucia & 68.3 & 73.2 & 68.6 & 68.5 & 70.1 & 48.7 & - & - & - & - \\
\hline $\begin{array}{l}\text { St. Vincent and the } \\
\text { Grenadines }\end{array}$ & 66.3 & 73.2 & 71.9 & 71.9 & 74 & - & - & - & - & - \\
\hline Sudan & 71.4 & 70.3 & 65.5 & 65.4 & 64.2 & 39.1 & 39.1 & 39.1 & 39.1 & - \\
\hline Suriname & 73.3 & 73.5 & 73 & 73 & 79.6 & - & - & - & - & - \\
\hline Swaziland & 74.9 & 72.9 & 72.7 & 72.7 & 73.5 & 53.9 & 53.9 & 53.9 & 53.9 & - \\
\hline Sweden & 85.3 & 81.9 & 80.6 & 80.3 & 79.4 & 47.8 & 46.1 & 48.6 & 48.6 & 48.6 \\
\hline Switzerland & 88.1 & 80.4 & 80.6 & 80.6 & 80.2 & 42.0 & 41.3 & 42.0 & 42.0 & 42.0 \\
\hline Tajikistan & 66.9 & 65.7 & 63.8 & 63.8 & 62.9 & 35.0 & 35.0 & 35.0 & 35.0 & - \\
\hline Tanzania & 67.8 & 66.8 & 66.7 & 66.6 & 64.5 & 40.4 & 39.5 & 39.5 & 39.5 & 39.5 \\
\hline Thailand & 70.1 & 76.8 & 79 & 82.6 & 82.5 & 40.3 & 38.7 & 38.7 & 38.7 & 38.7 \\
\hline Togo & 70.1 & 68.5 & 68 & 67.9 & 65.5 & 37.9 & 37.9 & 38.8 & 38.8 & 38.8 \\
\hline Tonga & 62.1 & 68.3 & 67.3 & 67.2 & 67.9 & - & - & - & - & - \\
\hline Tunisia & 73 & 68.6 & 68.3 & 68.2 & 74 & 38.9 & 38.9 & 38.9 & 38.9 & 38.9 \\
\hline Turkey & 70.4 & 84.4 & 84.2 & 83.7 & 84.3 & 40.5 & 41.4 & 41.1 & 41.1 & 41.1 \\
\hline Uganda & 70.4 & 69.5 & 69.7 & 69.6 & 68.8 & 46.0 & 43.5 & 43.5 & 43.5 & 43.5 \\
\hline Ukraine & 64 & 88.9 & 89.2 & 90 & 91.9 & 32.6 & 32.6 & 32.6 & 32.6 & 32.6 \\
\hline United Kingdom & 71.7 & 67 & 67.5 & 67.7 & 68.2 & 54.6 & 52.8 & 54.3 & 51.8 & 51.8 \\
\hline United States & 80.9 & 69.7 & 85.2 & 85.1 & 84.6 & 50.9 & 50.7 & 50.4 & 50.4 & 50.4 \\
\hline Uruguay & 81 & 71 & 69.8 & 69.8 & 77.7 & 50.5 & 48.4 & 49.2 & 49.2 & 49.2 \\
\hline Vanuatu & 67.6 & 68.1 & 67.3 & 67.1 & 67.2 & - & - & - & - & - \\
\hline Venezuela, RB & 72 & 80.6 & 79.6 & 82.5 & 81.8 & 40.3 & 39.4 & 36.6 & 36.6 & 36.6 \\
\hline West Bank and Gaza & 71 & 68.2 & 65.9 & 65.8 & 65.5 & - & - & - & - & - \\
\hline Yemen, Rep. & 70.1 & 67.5 & 66.9 & 66.8 & 65.6 & - & - & - & - & - \\
\hline Zimbabwe & 85.2 & 84.1 & 83.8 & 83.8 & 81.3 & - & - & 45.6 & 45.6 & 45.6 \\
\hline
\end{tabular}




\section{Appendix B: First-Stage GMM Estimation Results - P-Value of F Test of Excluded Instruments}

This table reports the results of the F-test of excluded instruments for all the estimations presented in Table 6 and in Table 7 of Section 4.

\begin{tabular}{|c|c|c|c|c|c|c|c|}
\hline Instrumented variables & 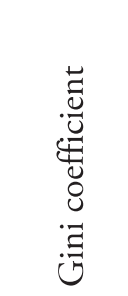 & 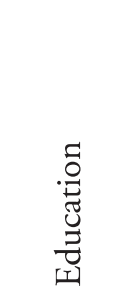 & 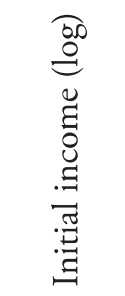 & 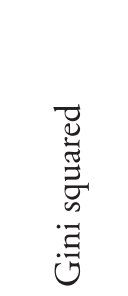 & 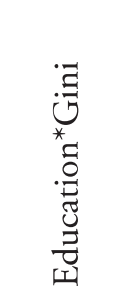 & 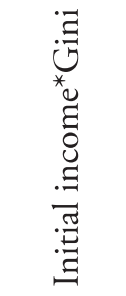 & $\begin{array}{l}\stackrel{\Xi}{\Xi} \\
\stackrel{*}{E} \\
\hat{\Xi}\end{array}$ \\
\hline $\begin{array}{l}\text { (7) GMM two-step, wealth Gini, } \\
146 \text { countries }\end{array}$ & 0.0000 & 0.0001 & 0.0000 & - & - & - & - \\
\hline $\begin{array}{l}\text { (8) GMM two-step, wealth Gini, with } \\
\text { continent dummies, } 146 \text { countries }\end{array}$ & 0.0000 & 0.0011 & 0.0003 & - & - & - & - \\
\hline $\begin{array}{l}\text { (9) GMM two-step, wealth Gini, with } \\
\text { squared Gini term, } 146 \text { countries }\end{array}$ & 0.0000 & 0.0001 & 0.0000 & 0.0000 & - & - & - \\
\hline $\begin{array}{l}\text { (10) GMM two-step, wealth Gini, } \\
\text { with interaction terms, } 146 \text { countries }\end{array}$ & 0.0000 & 0.0001 & 0.0000 & - & 0.0000 & 0.0000 & 0.0063 \\
\hline $\begin{array}{l}\text { (11) GMM two-step, income Gini, } \\
\text { with continent dummies, squared } \\
\text { Gini term and interaction terms, } \\
154 \text { countries }\end{array}$ & 0.0000 & 0.0000 & 0.0000 & 0.0000 & 0.0000 & 0.0000 & 0.0000 \\
\hline $\begin{array}{l}\text { (12) GMM two-step, only high } \\
\text { quality data on wealth Gini, with } \\
\text { interaction terms, } 114 \text { countries. }\end{array}$ & 0.0000 & 0.0000 & 0.0000 & - & 0.0000 & 0.0000 & 0.0118 \\
\hline $\begin{array}{l}\text { (13) GMM two-step, wealth Gini, } \\
\text { only rich countries, } 73 \text { countries }\end{array}$ & 0.0000 & 0.0336 & 0.0000 & - & - & - & - \\
\hline $\begin{array}{l}\text { (14) GMM two-step, wealth Gini, } \\
\text { only poor countries, with interaction } \\
\text { terms, } 73 \text { countries }\end{array}$ & 0.0000 & 0.0000 & 0.0000 & - & 0.0000 & 0.0000 & 0.0000 \\
\hline $\begin{array}{l}\text { (15) GMM two-step, wealth Gini, } \\
\text { only rich countries, with interaction } \\
\text { terms, } 73 \text { countries }\end{array}$ & 0.0000 & 0.0336 & 0.0000 & - & 0.0000 & 0.0000 & 0.0005 \\
\hline $\begin{array}{l}\text { (16) GMM two-step, wealth Gini, } \\
\text { only poor countries, } 73 \text { countries }\end{array}$ & 0.0000 & 0.0000 & 0.0000 & - & - & - & - \\
\hline $\begin{array}{l}\text { (17) GMM two-step, wealth Gini, } \\
\text { only rich countries, with Gini squared } \\
\text { and interaction terms, } 73 \text { countries }\end{array}$ & 0.0000 & 0.0336 & 0.0000 & 0.0000 & 0.0000 & 0.0005 & 0.0000 \\
\hline $\begin{array}{l}\text { (18) GMM two-step, wealth Gini, } \\
\text { only poor countries, with Gini } \\
\text { squared and interaction terms, } \\
73 \text { countries }\end{array}$ & 0.0000 & 0.0000 & 0.0000 & 0.0000 & 0.0000 & 0.0000 & 0.0000 \\
\hline
\end{tabular}




\section{References}

Adams, Richard H. (2004), "Economic Growth, Inequality and Poverty: Estimating the Growth Elasticity of Poverty", World Development, 32(12), 1989-2014.

Alesina, Alberto, and Dani Rodrik (1994), "Distributive Politics and Economic Growth", The Quarterly Journal of Economics, 109(2), pp. 465-490.

Arellano, Manuel, and Stephen Bond (1991), "Some Tests of Specification for Panel Data: Monte Carlo Evidence and an Application to Employment Equations". The Review of Economic Studies, 58(2), pp. 277-297.

Assa, Јасов (2012), "Inequality and Growth Re-Examined", Technology and Investment, 3(01), p. 1.

Atrinson, Anthony B., and Thomas Piketty (Eds.), (2010), Top Incomes: $A$ Global Perspective, Oxford University Press.

Atrinson, Anthony B., and Thomas Piketty (Eds.), (2007), Top Incomes over the Twentieth Century: A Contrast between Continental European and EnglishSpeaking Countries, Oxford University Press.

Bagchi, Sutirtha, and Jan Svejnar (2015), "Does Wealth Inequality Matter for Growth? The Effect of Billionaire Wealth, Income Distribution, and Poverty", Journal of Comparative Economics, 43(3), pp. 505-530.

Banerjee, Abhijit V., and Esther Duflo (2003), "Inequality and Growth: What Can the Data Say?”, Journal of Economic Growth, 8(3), pp. 267-299.

Barro, Robert J. (2008), "Inequality and Growth Revisited", No. 11, ADB Working Paper Series on Continent Economic Integration.

Barro, Robert J. (2000), "Inequality and Growth in a Panel of Countries", Journal of Economic Growth, 5(1), pp. 5-32.

Balisacan, Arsenio M., and Nobuhiko Fuwa (2003), "Growth, Inequality and Politics Revisited: A Developing-Country Case", Economics Letters, 79(1), pp. 53-58.

Barro, Robert J., and Xavier Sala-i-Martin (2003), Economic Growth, vol. 1, MIT Press Books.

Basu, Parantap, and Alessandra Guariglia (2007), "Foreign Direct Investment, Inequality, and Growth", Journal of Macroeconomics, 29(4), pp. 824-839.

Baum, Christopher F., and Mark E. Schaffer (2013), "A General Approach to Testing for Autocorrelation", retrieved May 7, 2015, http://www.stata.com/ meeting/new-orleans13/abstracts/materials/nola13-baum.pdf

Bleaney, Michael, and Akira Nishiyama (2004), "Income Inequality and Growth - Does the Relationship Vary with the Income Level?", Economics Letters, 84(3), pp.349-355. 
Castelló-Climent, Amparo (2010), "Inequality and Growth in Advanced Economies: An Empirical Investigation", The Journal of Economic Inequality, 8(3), pp. 293-321.

Chambers, Dustin, and Alan Krause (2010), "Is the Relationship between Inequality and Growth Affected by Physical and Human Capital Accumulation?", The Journal of Economic Inequality, 8(2), pp. 153-172.

Chen, Been-Lon (2003), "An Inverted-U Relationship between Inequality and Long-Run Growth", Economics Letters, 78(2), pp. 205-212.

Clarke, George R. G. (1995), "More Evidence on Income Distribution and Growth", Journal of development Economics, 47(2), 403-427.

Corneo, Giacomo, Timm Bönke, and Holger Lüthen (2015), "Lifetime Earnings Inequality in Germany", Journal of Labor Economics, 33, pp. 171-208.

Davies, James B., Rodrigo Lluberas, and Anthony F. Shorrocks (2014), "Global Wealth Databook", Zürich: Credit Suisse Research Institute.

Davies, James B., Rodrigo Lluberas, and Anthony F. Shorrocks (2013), "Global Wealth Databook", Zürich: Credit Suisse Research Institute.

Davies, James B., Rodrigo Lluberas, and Anthony F. Shorrocks (2012), "Global Wealth Databook", Zürich: Credit Suisse Research Institute.

Davies, James B., Rodrigo Lluberas, and Anthony F. Shorrocks (2011), "Global Wealth Databook", Zürich: Credit Suisse Research Institute.

Davies, James B., Rodrigo Lluberas, and Anthony F. Shorrocks (2010), "Global Wealth Databook", Zürich: Credit Suisse Research Institute.

Davies, James B., Susanna Sandström, Anthony Shorrocks and Edward N. WolfF (2011), "The Level and Distribution of Global Household Wealth", The Economic Journal, 121(551), pp. 223-254.

De La Croix, David, and Matthias Doepke (2003), "Inequality and Growth: Why Differential Fertility Matters", The American Economic Review, 93(4), pp. 1091-1113.

Deininger, Klaus, and Pedro Olinto (1999), "Asset Distribution, Inequality, and Growth", World Bank policy research working paper (2375).

Deininger, Klaus, and Lyn Squire (1998), "New Ways of Looking at Old Issues: Inequality and Growth", Journal of development economics, 57(2), pp. 259-287.

Easterly, William (2007), "Inequality Does Cause Underdevelopment: Insights from a New Instrument", Journal of Development Economics, 84(2), pp. 755-776.

Fallah, Belal N., and Mark Partridge (2007), "The Elusive Inequality-Economic Growth Relationship: Are There Differences between Cities and the Countryside?", The Annals of Continent Science, 41(2), pp. 375-400. 
Forbes, Kristin J (2000), "A Reassessment of the Relationship between Inequality and Growth", American Economic Review, pp. 869-887.

Gylfason, Thorvaldur, and Gylfi Zoega (2003), "Inequality and Economic Growth: Do Natural Resources Matter?", Inequality and Growth: Theory and Policy Implications, 1, 255.

Grijalva, Diego F. (2011), "Inequality and Economic Growth: Bridging the Short-run and the Long-run", Working Paper, University of California, Irvine.

Herzer, Dierk, and Sebastian Vollmer (2012), "Inequality and Growth: Evidence from Panel Cointegration", The Journal of Economic Inequality, 10(4), pp. 489-503.

Iradian, Garbis (2005). Inequality, Poverty, and Growth: Cross-Country Evidence, International Monetary Fund.

Keefer, Philip, and Stephen Knack (2002), "Polarization, Politics and Property Rights: Links between Inequality and Growth", Public choice, 111(1-2), pp. 127-154.

Knowles, Stephen (2005), "Inequality and Economic Growth: The Empirical Relationship Reconsidered in the Light of Comparable Data", The Journal of Development Studies, 41(1), pp. 135-159.

Kostov, Philip, and Julie Le Gallo (2015), "Convergence: A Story of Quantiles and Spillovers", Kyklos, 68(4), 552-576.

Kuznets, Simon (1955), "Economic Growth and Income Inequality”, The American Economic Review, pp. 1-28.

Li, Hongyi, and Heng-fu Zou (1998), "Income Inequality is not Harmful for Growth: Theory and Evidence", Review of Development Economics, 2(3), pp. 318-334.

Lin, YI-Chen, and Chin-Chuan Yeh (2009), "Joint Determinations of Inequality and Growth", Economics Letters, 103(3), pp. 163-166.

Mo, Pak Hung (2000), "Income Inequality and Economic Growth", Kyklos, 53(3), pp. 293-315.

Noh, Yong-Hwan, and Kyeongwon Yoo (2008), "Internet, Inequality and Growth", Journal of Policy Modeling, 30(6), pp. 1005-1016.

Pagano, Patrizio (2004), "An Empirical Investigation of the Relationship between Inequality and Growth”, Vol. 536, Banca d'Italia.

Perotti, Roberto (1996), "Growth, Income Distribution, and Democracy: What the Data Say", Journal of Economic Growth, 1(2), pp. 149-187.

Persson, Torsten, and Guido Tabellini (1994), "Is Inequality Harmful for Growth?”, The American Economic Review, 84(3), pp.600-621. 
Piketty, Thomas, and Gabriel Zucman (2015), "Wealth and Inheritance in the Long Run", in Handbook of Income Distribution, Anthony Atkinson and François J. Bourguignon, eds., vol. 2B, Elsevier, ch. 15, pp. 1303-1368.

Pinetty, Thomas, (2014), Capital in the $21^{\text {st }}$ Century, Cambridge: Harvard University press.

Ravallion, Martin (2012), "Why Don't We See Poverty Convergence?", The American Economic Review, pp. 504-523.

Ravallion, Martin (1995), "Growth and Poverty: Evidence for Developing Countries in the 1980s", Economics Letters, 48(3), pp.411-417.

Saint-Paul, Gilles, and Thierry Verdier (1993), "Education, Democracy and Growth", Journal of Development Economics, 42(2), pp. 399-407.

Solt, Frederick (2014), "The Standardized World Income Inequality Database", Working paper, SWIID Version 5.0, October 2014.

Solt, Frederick (2009), "Standardizing the World Income Inequality Database”, Social Science Quarterly, 90(2), pp. 231-242.

Sukiassyan, Grigor (2007), "Inequality and Growth: What Does the Transition Economy Data Say?", Journal of Comparative Economics, 35(1), pp.35-56.

Voitchovsky, Sarah (2005), "Does the Profile of Income Inequality Matter for Economic Growth?”, Journal of Economic Growth, 10(3), pp. 273-296.

Wan, Guanghua, Ming Lu, and Zhao Chen (2006), "The Inequality-Growth Nexus in the Short and Long Run: Empirical Evidence from China", Journal of Comparative Economics, 34(4), pp. 654-667. 